\title{
Basque Differential Object Marking as a Contact- Induced Phenomenon: How and Why?
}

\author{
Itxaso Rodríguez-Ordóñez \\ Assistant Professor, Department of Linguistics, California State University \\ Long Beach, United States of America \\ itxaso.rodriguez@csulb.edu
}

\begin{abstract}
The debate as to whether syntax can be borrowed has spurred much scholarly inquiry among those who argue that syntax cannot be borrowed (Silva-Corvalán, 2008) and those in favor of the 'anything-goes' argument (Thomason, 2001). In contribution to this debate, this study examines the contact-induced processes behind the variation of Basque Differential Object Marking (Dом). We examine the use of Basque Dом in the spontaneous speech of 42 speakers whose variety has been in a long-standing contact with Spanish (Gernika Basque) and 15 speakers of a 'newly' standardized variety (Standard Basque). We additionally examine the spontaneous speech of their leísmo in order to make a case that Basque Dом is not an example of syntactic borrowing but involves a process of replica grammaticalization (Heine and Kuteva, 2005) whereby speakers replicate their use of leísmo either through matter-borrowing, patternborrowing or a combination of both.
\end{abstract}

\section{Keywords}

Basque Dом - Spanish leísmo - replica grammaticalization

\section{Introduction}

Differential Object Marking (DOM, henceforth) is a well-attested crosslinguistic construction whereby certain objects get differently marked depending on a number of factors (Bossong, 1995; Aissen, 2003; Hopper and Thompson, 1980; Næss, 2004). The two strategies associated with DOM are known to 
be Differential Object Flagging (DOF), when an object may be flagged with case-marking or Differential Object Agreement (DOA), when the object agrees with the inflected verb (Haspelmath, 2005; Coghill, 2014). Basque, an isolate language spoken in northern Spain and southwest France, is a language that presents variable cases of DOM in the shape of DOF and DOA. As shown in (1a), the direct object Mikel gets case-marked (or flagged) with the dative case -ri and agrees with the pronominal morpheme - $o$ - in the auxiliary verb. Example (1b) shows its counter non-Dom example, also available in Basque.

Standard Basque

I-E RG Mikel-vo

ikusi $d-i-o_{i}-t$.

'I have seen Mikel.'

$\begin{array}{llll}\text { b. } & \text { Ni-k } \quad \text { Mikel } & \text { ikusi } & d \text {-u-t. } \\ \text { I-ERg } & \text { Mikel.ABs } & \text { see } & \text { L-3SG.PRS-1SG.ERG } \\ \text { 'I have seen Mikel.' } & & \end{array}$

Basque Dом has been argued to be the result of intense contact with Spanish and more specifically, to the use of leísmo spoken in the Basque Country (Rodríguez-Ordóñez, 2016, 2017), known as the Basque Leísta Dialect (BLD) (Ormazábal and Romero, 2013).

Basque Leísta Dialect (BLD)
a. Le
he
visto
a Mikel.
LEÍ́smo 1SG.have see.PART DOM Mikel 'I have seen Mikel.'

As shown in (1a) and (2a), both Basque and Spanish share two mechanisms of encoding DOM: for Spanish, Dом is encoded using either the dative third person pronoun le along with a-marking (also used for indirect objects); for Basque, the dative postposition $-r i$ is used to mark certain objects along with their morphological affixes in the auxiliary verb. Despite the apparent similarities behind these two constructions, the mechanisms that may have led to the emergence of Basque DOM as a contact-induced phenomenon remain understudied. The goal of this paper is to examine those mechanisms by situating the study within wider theoretical debates as to whether syntactic borrowing is possible. 
The rest of the paper is structured as follows: Section 2 discusses the main theoretical debates with respect to syntactic borrowing. In section 3, an overview of the Basque-Spanish contact situation is presented. In section 4, we discuss previous work on Basque DOM and Basque Leísta Dialect (BLD). Section 5 discusses the methodologies and coding criteria used for the analysis of the present study. In section 6 , results are presented followed by a discussion in section 7 and conclusions in section 8 .

The study of contact-linguistics has long established that cross-linguistic influence is neither random nor unconstrained (Thomason and Kaufman, 1988, 2001; Heine and Kuteva, 2005, 2006; Matras, 2010). When it comes to crosslinguistic influence at the grammatical level, however, there is considerable debate as to whether syntax can be borrowed. On the one hand, the 'anythinggoes' view (Matras, 1998) suggests that any linguistic material can be borrowed given enough social pressure (Thomason and Kaufman, 1998:14; Campbell, 1993:104). On the other hand, proponents arguing against the 'anything-goes' view claim that syntactic structures rarely get borrowed (Windford, 2003:97) and that grammatical borrowing occurs at its interfaces (i.e. semantics, lexicon) with implications for grammatical change under contact (King, 2000; Snakoff, 2002; Silva-Corvalán, 1998, 2008).

The roots of these opposing views can be attributed to larger theoretical questions that revolve around what constitutes syntax and how we operationalize 'structural borrowing' or 'borrowing' in general. With respect to the notion of syntax, generative approaches to syntactic theory generally claim that speakers' syntactic knowledge is projected from the lexicon, which are elements that are used in a computational system to generate derivation (Chomsky, 1993:2). The Principles and Parameters suggests that all languages have a set of principles and the variation found within the worlds' languages depend on a number of parametrizable settings. As such, it is argued that the P\&P framework limits the type of constraints of possible grammatical borrowing (King, 2000). For instance, Lefebvre (1984) argues that assuming a category exists in a given language, any lexical item could be borrowed into that language, rendering syntactic borrowing impossible. ${ }^{1}$ The functionalist tradition

1 This does not mean that syntax cannot change. See Lightfoot (1991) and Roberts and Roussou (2003) for a discussion. But it suggests that syntax is not borrowable, only the parameters that are specified in the lexicon are transferrable. 
to syntax views the syntactic-semantic specifications in a non-modular continuum, whereby grammar constitutes a constantly changing 'form-function' representation of linguistic knowledge (Croft, 2000; Tomasello, 2003; Bybee, 2008).

Another challenge in determining whether syntax can be borrowed or not is related to terminology. The tern 'borrowing' was used by Thomason and Kaufman (1988) to refer to 'the incorporation of foreign features into a group's native language by speakers of that language' (p. 37). This term was used to differentiate borrowing from 'shift-induced interference,' or changes that involve cases of language shift. This same type of change has also been named 'transfer' (Hickey, 2010: 18) whereas others have used the term 'borrowing' as an umbrella term to refer to the transportation of linguistic material 'from one language to another' (Heine and Kuteva, 2005:6), ${ }^{2}$ equating transfer to 'effects' of contact-induced change. With respect to cross-linguistic influence at the grammatical level, Heine and Kuteva $(2005,2006,2010)$ (H\&K, henceforth) argue that certain contact-induced processes are more complex than what the broad terms 'borrowing' or 'transfer' may capture and propose a framework of contact-induced grammaticalization that captures the way certain structures may be replicated from the donor language.

The third challenge in the study of language contact is to establish whether a particular change has occurred because of contact. Broadly speaking, 'contact-induced change' has been defined as 'a linguistic change that would have been less likely to occur outside a particular contact situation' (Thomason 2001:62). Different criteria have been proposed to establish a satisfactory argument in favor of contact-induced case and most, though not all, agree that in order to successfully attribute a change to contact, the presumed contact feature needs to be present in the source language or variety, and either 1) absent in a pre-contact variety of the recipient language (Thomason, 2001:93-94; 2010:34; Mougeon et al., 2005; Poplack and Levey, 2010: 398) or 2) if present, it needs to be demonstrated that the innovation is not conditioned in the same way as in the source. The ability to demonstrate absence of the presumed contact feature in a pre-contact variety is an idealization that can be applicable a limited set of contact scenarios (Thomason, 2001:94). Pre-contact data in Basque is non-existent and the language is currently spoken by speakers who are bilingual in either French or Spanish. This constraint then warrants further methodological innovations in examining contact-induced phenomena.

2 This definition of 'transfer' is equally treated as what Weinreich (1953) called 'interference'. For further discussion see Sankoff (2002) or Matras and Sakel (2007). 
For our purposes, the present study compares the speech of Basque-Spanish bilinguals who speak a regional dialect that has been in long-standing contact with Romance languages with the speech of 'new' Basque-Spanish bilinguals who have only been exposed to the recently standardized variety (1960s) of Basque. Additionally, we incorporate a small sample of the Basque varieties spoken by Basque-French bilinguals in the Eastern part of the Basque Country. These comparisons will allow us to disentangle Basque-Spanish long-term contact effects from individual bilingualism and trace potential processes of grammaticalization that should be absent among Basque-French bilinguals, given that French (at least the variety spoken in the Basque Country) lacks DOM.

The present study applies a quantative variationist method to H\&K's framework, to determine the mechanisms by which Basque Doм is the result of intense contact with Spanish. Results provide evidence that Basque Dом is not an example of syntactic borrowing, but constitutes more complex mechanism that can be captured through H\&K's (2005) replica grammaticalization, whereby speakers may borrow material through matter-borrowing, patternborrowing or a combination of both.

Basque is an isolate language ancestral to the Basque County (located in northern Spain and southwestern France). With no commonly united administration, the Basque Country refers to all seven provinces that are divided into two nation-states: the provinces of Bizkaia, Gipuzkoa and Araba make up the Basque Autonomous in Spain (BAC), where Basque enjoys a co-official status with Spanish. The Autonomous Community of Navarre, also in Spain, constitutes its own territory and Basque has a more restricted official status. The provinces of Lapurdi, Low Navarre and Zuberoa comprise the western half of the Départment des Pyrenées Atlantiques where Basque has no-official status.

The initial contact between Basque and Romance languages has generally been claimed to be that of diglossic bilingualism: Basque was mainly used in rural areas and associated with agriculture, illiteracy and 'backwardness' (Trask, 1997; Zuazo, 2005). This situation drastically differs to the situation in the Basque Autonomous Community where a more-widespread bilingualism exists today. Two factors aided in this shift. First, a standardized variety of Basque (Euskara Batua, literally 'Unified Basque,' also referred to as Standard 
Basque, SB henceforth $)^{3}$ was created in 1968. Basque became co-official with Spanish in 1979 in this territory and the act of normalization in 1982 allowed for the implementation of Standard Basque as the medium of instruction in the public education system. These factors lead to a massive increase in bilingual literacy and growth; Up until the death of Franco in 1975, it was estimated that the use of Basque barely reached $25 \%$ of its population. Today, $53 \%$ of the Basque Autonomous Community in Spain reports knowing some Basque (of which $19.1 \%$ claim to be a passive bilingual, meaning that they understand it but do not speak it). The increase of Basque speakers in the BAC is much larger depending on the age group. In 1991, it was reported that $25 \%$ of the population between 16 and 25 years of age were Basque speakers, as compared to $71.4 \%$ today (Eusko Jaurlaritza, 2016). The new educational regulations led to the creation of a more diverse bilingual population as well; while most Basque speakers in the 1980 s were native speakers, the L2 population (known as euskaldunberriak 'new speakers of Basque') constitutes almost $40 \%$ of the Basquespeaking population in the BAC today, with $53 \%$ of those speakers under the age of 35 (Eusko Jaurlaritza, 2013:5).

It is important to note that the linguistic profiles of these bilinguals represent the diglossic situation of a few centuries back: whereas the majority of SB speakers mainly reside within larger urban areas where Basque was not spoken before the standardization, native speakers are known to speak a 'home' dialect and typically grew up in rural or semi-urban areas where a local dialect has been preserved. The present study is aimed at locating contact effects of Basque Dом among native speakers of a regional dialect, that of Gernika (Gernika Basque, GB henceforth) and speakers of SB from the Greater Bilbao area, who began learning Basque as early as the age of three, whom I call 'early sequential bilinguals'.

The comparison of these two kinds of bilinguals presents an opportunity to disentangle long-term language contact effects from more recent contacts as these two groups represent slightly, yet comparable sociolinguistic contexts. The regional variety of GB is spoken in Gernika, a semi-urban town located 34 $\mathrm{km}$ (21.2 miles) from the capital of the Bizkaian province of Bilbao, in the Western side of the Basque Autonomous Community (BAC) in Spain. Gernika has approximately 16,000 inhabitants and it is one of the largest towns that surround rural villages with a long agricultural presence. One of the notorious aspects of the town is its industrial importance, especially in the 6os, which

3 The two main procedures to create Standard Basque were what Haugen (1972:109) called archaizing and statistical procedures, which meant that the new variety would have strong links to literary tradition and would be complemented with forms that had the widest usage, respectively. 
attracted a great influx of Spanish monolingual residents. ${ }^{4}$ Many of these families learned Basque, or had children that learned Basque through the immersion programs that were established after 1982, increasing the presence of Basque in the town: $61.1 \%$ of the population in Gernika showed some sort of knowledge of Basque in 1981, whereas nearly $70 \%$ of the population speaks the language natively today. In terms of education, only $30 \%$ of children were enrolled in a full Basque immersion program at school in 1981, whereas $100 \%$ of children are instructed entirely in Basque today (Gernikako Udala, 2002). The same survey shows that although Basque is spoken by a high percentage of the population, Spanish is also commonly used: $35 \%$ of the population use only Spanish at home as opposed to $41 \%$ who speak only Basque at home. An additional $22.9 \%$ of the population in Gernika report speaking both languages at home.

Bilbao, on the contrary, is the largest city in the Basque Country with a population of 353,187 in the inner city and 950,155 in its metropolitan area (Instituto Nacional de Estadística (INE), 2015), which comprises $43.5 \%$ of the entire Basque population (roughly 2.2 million). The annexation of nearby municipalities from Bilbao (Barakaldo, Getxo, Portugalete, etc.) was promoted by the population growth that derived from a powerful industrialization process during the late 19th and early 2oth centuries and again in the 1960s. Similar to Gernika, many monolingual speakers of Spanish settled in the surrounding areas in Bilbao during the 1960s, at a time in which the iron industry was revitalized, thereby doubling its population from 230,000 to 411,000 in less than two decades (INE, 2015). Unlike the bilingual situation in Gernika, Basque had already become extinct (or nearly) in the Greater Bilbao area long before the great influx of immigration. After the strong revitalization efforts during the 1970 and 1980 s, the presence of Basque started to gain terrain where most bilinguals use the Standard variety of Basque. It is estimated that $52.1 \%$ of the speakers in Bilbao are highly competent in Basque (mostly under the age of 35). In terms of usage though, Bilbao differs greatly from Gernika: $91 \%$ of the people report speaking only Spanish at home as opposed to $2.9 \%$ who use Basque at all times. Only 3.8\% report speaking both Basque and Spanish at home (Eusko Jaurlaritza, 2016).

The two target populations studied here are similar in the sense that they had early exposure to the Basque language, either since birth or from early childhood (as early as 2 years of age). They differ however, in two important ways: first, Basque speakers in Gernika generally speak the regional dialect

4 According to Eustat, the Basque Statistic Office, the population living in Gernika doubled from 7,847 to 14,678 in the 1960 . 
(GB), which has been in contact with Romance languages for centuries. Basque speakers in Bilbao (at least the participants in the present study), have only been exposed to the newly standardized variety (SB) through the education system. Second, given the current sociolinguistic situation in the BAC, the daily use of Basque as well as the domains in which Basque is used in the semiurban area of Gernika is much higher; the SB speakers from the Bilbao area have reported using Basque and Spanish in a reversed diglossic situation, by having limited access to their use of Basque outside of the school setting.

The present study also includes a small sample from Basque spoken in Iparralde, a variety of Basque in contact with DOM-less French. This comparison allows us to demonstrate that Basque Dом is indeed a contact-induced phenomenon given its absence in this territory. The legal situation of Basque in Iparralde or in the French Basque Country shows certain differences from the BAC in Spain. According to the French Constitution, French is the sole official language of France (article 2.1.). Despite constitutional monolingualism, the use of regional languages has enjoyed some flexibility according to the L 121-1 article, which has led the implementation of bilingual programs in the area (López-Basaguren, 2012). Such programs have also given rise to a small group of 'new speakers' ( $9 \%$ of total population) (Eusko Jaurlaritza, 2012), as the majority of Basque speakers in Iparralde are considered native speakers who have acquired the language via family transmission. In the present study, a total of 15 Basque-French bilinguals were recruited from the city of Baiona and its surroundings (Itxassou, Ustaritz, Kambo, Angelu, Hazparne, Donibane Lohitzune, etc). Baiona is the largest city of Iparralde and the capital of the province of Lapurdi. The greater Baiona-Angelu-Biarritz area (BАВ) Baiona-Angelu-Biarritz (ВАВ) is home to approximately 90,000 inhabitants, of which only $13 \%$ report knowing Basque to a certain extent (Eusko Jaurlaritza, 1996). The surrounding areas of ВАВ comprise smaller towns that are semi-urban or rural in nature, whose population totals 86,000 altogether. In these towns, the number of bilinguals is relatively higher $(43 \%)$. These bilinguals serve as a control group and their use of Basque is compared to those Basque-Spanish bilinguals.

\section{Dom: Basque and Spanish}

\subsection{Basque}

Basque is an ergative-absolutive language with ergative, absolutive and dative case markings assigned to different syntactic functions (Ortiz de Urbina, 1989; Etxepare, 2003). Transitive and unergative subjects are usually assigned an ergative $-(e) k$ case marking. Direct objects are generally $-\emptyset$ marked as absolutives and dative $-(e) r i$ is generally used to mark indirect objects, benefactives 
or goals. Basque verbs are composed of a lexical verb that carries aspectual information and an auxiliary verb bearing tense, agreement and modal information. Basque ром (за), despite being prescriptively associated with ungrammaticality (Zubiri, 1991) is expressed by means of dative $(-r i)^{5}$ in the NP and a morpheme (-o-) in the auxiliary verb. Basque Dом is optional (at least in the third person), as it competes with its canonical form (3b):

Standard Basque

$$
\text { a. Ni-k Mikel-e-ri } i_{i} \quad \text { ikusi } d-i-o_{i}-t \text {. }
$$

I-ERG Mikel-voWEL-DAT see L-3SG.PRS-3SG.DAT-1SG.ERG

'I have seen Mikel.'

$\begin{array}{llll}\text { b. } & \text { Ni-k } \quad \text { Mikel } & \text { ikusi } & d-u-t . \\ \text { I-ERG } & \text { Mikel.ABS } & \text { see } & \text { L-3SG.PRS-1SG.ERG } \\ \text { 'I have seen Mikel.' } & \end{array}$

From a theoretical perspective, it has been previously argued that Basque DOM follows two general principles (Fernández and Rezac, 2010, 2016; Odria, 2017:1) syntactically, DOM objects are direct objects because they share the same argument relations as canonical objects and 2) morphologically, DOM objects have structural case-marking in which they agree with the clitic in the auxiliary verb. A test to determine that DOM objects are true direct objects is to use depictive predicates (McFadden, 2004) by which depictive secondary predicates can only be controlled by direct objects and not indirect objects (Pylkkänen, 2002). In this respect, (4a) constitutes an example of Dom whereby the depictive predicate mozkortuta 'drunk' can modify either the subject or the direct object. On the contrary, (4b) is not an example of 'true' Dom because mozkortuta 'drunk' cannot modify the direct object zuri 'you-DAT'. As such, verbs like begiratu 'to look at' are considered alternating and do not constitute true cases of DOM if marked with dative. ${ }^{6}$

Standard Basque (Fernández and Rezac 2016:111)

$$
\begin{aligned}
& \text { a. Ni-k } k_{i} \quad z u-r i_{j} \quad \text { mozkortuta }_{i j} \text { ikusi } d-i-z u_{j} t_{i} \\
& \text { I-ERG you-DAT drunk see L-3SG.PRS-2SG.DAT-1SG.ERG } \\
& \text { 'I saw you drunk.' }
\end{aligned}
$$

5 The use of the dative marker to denote Dom objects is cross-linguistically common (Bossong, 1985; Sinnemäki, 2014) and is generally used for indirect objects.

6 Another aspect that distinguishes true Dом from dative-marking in alternating verbs is that true Dом is restricted to animacy whereas inanimate objects can be dative-marked with alternating verbs (Odria, 2014; Fernández and Rezac, 2016). 
(4)
b. $\quad N i-k_{i} \quad z u-r i_{j}$
mozkortuta $_{i^{\prime * j} j}$
begiratu
$d-i-z u_{j} t_{i^{*}}$
I-ERG you-DAT drunk
look.at
L-3SG.PRS-2SG.DAT-1SG.ERG
'I looked at you drunk.'

The argument that Dom dative objects bear structural case comes from the fact that Basque DOM can appear in Exceptional Case Marking (ЕСM) contexts. Under the minimalist program on Case Theory (Chomsky, 200o) structural case marking reflects the Agree/Case relationship between the locus of case ( $\mathrm{v}$ for direct objects), and the argument. Exceptional Case Marking refers to the morphological case marking procedure of the embedded subject in an infinitival sentence. In Basque, transitive structures with eduki 'to have' have been analyzed for ECM conditions (Etxepare and Uribe-Etxebarria, 2012; Fernández and Rezac, 2016), in which eduki 'to have' may take a small clause with subject-predicate relation as its complement as in $(5 \mathrm{a})$ :

Basque (Fernández and Rezac 2016:116)
a. [Oier artzain $]$ d-eko-gu
Nevada-n
Oier shepherd L-3SG.PRS-1PL.ERG Nevada-Loc
'Oier is a shepherd in Nevada.'
(literally = we have Oier (working) as a shepherd in Nevada)

Ithas previously been argued that Basque Dом is optionally restricted to human and specific objects. However, the person feature of the object has shown important dialectal differences in terms of the use of Basque DoM. For instance, in dialects such as Elgoibar Basque, Dом is obligatory with first- and second-person objects and optional with third person ones (Odria, 2014, 2017). ${ }^{7}$ Likewise, Dima and Ultzama DOM is also obligatory with first and second person but unavailable for third person objects (Monoule, 2012; Fernández and Rezac, 2016), and in Lekeitio Basque, DOM is optional with any person (Hualde et al., 1994). Whether Basque dialects mark third person animate objects with dative or not, all dialects seem to show higher rates of DOM with first and second person. This fact was quantitatively shown for Gernika Basque (Rodríguez-Ordóñez, 2016, 2017) in which first and second person objects almost categorically (up to 96\%) select dative whereas only $6 \%$ of third person objects were marked with dative.

In terms of the properties of the clause, it has been previously shown that Basque ром is also conditioned by tense, finiteness and agreement. For instance, Yrizar's (1997) descriptions of Gipuzkoan verbal paradigms show that

7 More recently, Odria (2017) shows that Dom is optional for first, second and third person animate and specific objects in Elgoibar Basque. 
Basque Dом is restricted to the past tense. Others have shown that Basque DOM appears both in present and past tense in dialects such as Hondarribia, Irun (Sagarzazu, 2005) and Lekeitio Basque(Hualde etal., 1994). These results seem to suggest that Basque Dом first appears in the past tense and then may extend to the present tense. Although it is unclear how the subcomponents of finiteness and agreement may contribute to Basque Dom (Fernández and Rezac, 2016), it has been shown that Basque Dом can appear both with finite and non-finite clauses.

Another factor that has been given less scholarly attention is how the pro(noun) drop characterization of Basque favors Dom in Basque. Austin (2006) hypothesizes that null objects may open a window for reanalysis in Basque, claiming that DоM is more likely to occur in the auxiliary verb when the DP is not phonologically encoded. This hypothesis was quantitatively proven in Rodríguez-Ordóñez (2017) at least for Gernika Basque. An example is represented in (6) in which DOM appears with a null NP but recovered through the agreement morpheme -i- in the auxiliary verb.

Gernika Basque

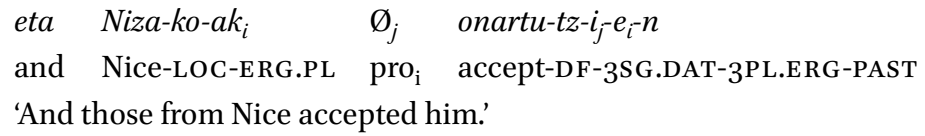

In the same work, it was further shown that null objects interact with a certain type of verbs (i.e. Spanish borrowings) in favoring Basque but it still remains to understand how the lexical semantics of verbs may also favor Basque DoM. We address this factor in the present study.

\subsection{Spanish}

Spanish Differential Object Marking (DOM) can be expressed by means of flagging ( $a$-marking), indexing (clitic-doubling) or clitic case form (le/les). The variety of Spanish spoken in the Basque Country (Basque-Spanish) ${ }^{8}$ exhibits all these three phenomena, as shown in (7):

Basque Leísta Dialect (BLD)

$\begin{array}{lllll}\text { (7) Le } & \text { he } & \text { visto } & a & \text { Mikel. } \\ \text { LEÍsmo } & \text { 1SG.have } & \text { see.PART } & \text { DOM } & \text { Mikel. } \\ \text { 'I have seen Mikel.' } & & & \end{array}$

8 We use Ormazábal and Romero's (2013) term Basque Leísta Dialect (BLD) to refer to the type of leísmo used in Basque Spanish. 
To date, it is unknown whether Peninsular varieties present ample variation in the use of a-marking (Tippets, 2011). However, research on leismo, has shown that the Spanish-speaking populations show a great deal of variation with respect to its use and the type of leísmo they employ (Fernández-Ordóñez, 1999, 2012; Camacho and Sánchez, 2002; Palacios, 2006; DeMello, 2002). The BasqueSpanish Leísta Dialect (BLD) is characterized by its animate leísmo, in which the use of le or lo/la depends on the animacy of the object. As such, animate leísmo refers to the use of le to index animate direct objects regardless of gen$\operatorname{der}(8)$ or number $(8 \mathrm{a}-\mathrm{d})$ :

Basque Leísta Dialect (Ormazábal and Romero 2013:316)

$\begin{array}{lllllll}\text { Le } & v i & (a l & \text { niño } & \text { /a } & \text { la } & \text { niña }) \\ \text { LEÍsmo } & \text { 1SG.saw } & \text { Dom.the } & \text { boy } & \text { Dом } & \text { the } & \text { girl } \\ \text { 'I saw him/her/the boy/the girl.'. }\end{array}$

Clitic-doubling is another site for variation in the Spanish-speaking world which interacts with leismo. In Standard Spanish, clitic doubling is obligatory with clitic left dislocations and possible with arguments that double indirect objects (Zagona, 2002). In BLD, clitic-doubling may appear with inanimate objects that are encoded with accusative $l o / l a(9)$ :

Basque Leísta Dialect (Urrutia-Cárdenas 2003:530)

$\begin{array}{lllll}\text { (9) Yo } \quad l o_{i} & \text { veo } & \text { el } & \text { castellano }_{i} & \text { igual } \\ & \text { 3SG.M.ACC.CL } & \text { 1SG.see } & \text { the }_{\mathrm{M}} & \text { Spanish same }\end{array}$

'I see Spanish as the same.'

Unlike Standard Spanish, BLD clitic doubling may appear with negative quantifiers when encoding animate objects (1ob) but it is not possible with inanimate ones (10a).

Basque Leísta Dialect (Ormazábal and Romero 2013:317)

$\begin{array}{llllllll}\text { (10) } & a . & { }^{*} \text { Ningún } & \text { libro }_{i} & l o_{i} & \text { han } & \text { visto en la universidad } \\ & \text { None } & \text { 1sg.see } & \text { 3SG.M.ACC.CL } & \text { have.they } & \text { seen in the } \\ & & \text { iniversity }\end{array}$ 'They have not seen any book at the university'

(10) b. A ningún estudiante $e_{i}$ le $e_{i}$ han visto en la universidad DOM none student 3SG.M.ACC.CL have.they seen in the $\mathrm{F}_{\mathrm{F}}$ university 'They saw no student at the university.' 
This characterization of clitic-doubling in BLD has led researchers to postulate two conclusions: first, the presence of clitic doubling is largely conditioned by the presence of DOM, conforming thus to Kayne's Generalization (UrrutiaCárdenas and Fernández-Ulloa, 1997; Zdrojewski and Sánchez, 2014), and second, the presence of clitic-doubling in BLD is a syntactic phenomenon. More specifically, it is claimed that the direct object le/les in BLD are no different from indirect object le/les, which follows the general assumption that that indirect object clitics (le/les) are agreement markers: clitics are heads containing their own agreement projections and function as morphological agreement markers, in which they agree with case, number, person and animacy (Franco, 1993; Sportiche, 1996; Ormazábal and Romero, 2013). Thus, Basque Doм and BLD are similar with respect to two factors: 1 ) both systems structurally assign dative to their animate direct objects ( $a$-marking in Spanish; - $r$ in Basque) and 2) their syntactic representation of clitic-doubling is characterized by their pronominal status as agreement markers in both systems. It has been previously demonstrated that Basque DOM is the result of contact with BLD (Rodríguez-Ordóñez, 2016, 2017). ${ }^{9}$ However, the mechanisms that led to the emergence of Basque DOM as a contact-induced phenomenon remains understudied. The goal of this paper is, therefore, to examine those mechanisms and to situate the present study within wider theoretical notions of syntactic borrowability in order to establish whether Basque Dom is an example of syntactic borrowing.

\section{5}

The study

To this end, the present study examines the spontaneous speech of 57 BasqueSpanish bilinguals and 15 Basque-French bilinguals. The spontaneous speech of Basque and Spanish was gathered by means of semi-directed sociolinguistic interviews (Labov, 2001) during the summers of 2013 and 2014; each one lasted between $45^{-60}$ minutes in each language. Participants were encouraged (but not restricted) to share anecdotes from their childhood, discuss how they felt affected by the economic crisis in Spain and plans they may have had for the rest of the summer. Data were collected in a place of the speaker's choice, which included their work space, their home or regularly visited cafés. Participants were asked to speak in the register of Basque that they were most

9 It has been proposed that the development of BLD is the result of long-standing contact (Fernández-Ordóñez, 2012). Such hypothesis, although relevant and of great importance, is not pursued in the present study. 
comfortable with (own dialect or standard Basque) and Spanish. In order to avoid 'language mode' effects (Grosjean, 2008), data were collected in two sessions (one in Basque and in Spanish).

\subsection{Social factors}

Two different target Basque-Spanish bilingual groups are being examined in the present study: Basque-Spanish native bilinguals and Spanish-Basque early sequential bilinguals. Forty-two native bilinguals were recruited from the semi-urban area of Gernika, all of whom spoke the regional dialect of the town, Gernika Basque. Fifteen Early sequential bilinguals, who speak Standard Basque were recruited from the Greater Bilbao area. A group of fifteen BasqueFrench bilinguals were incorporated as a control group. Participants were asked to complete a language background questionnaire that tapped into their sociolinguistic background (i.e. age at which they started learning Basque, education years learning Basque, the use of Basque and Spanish in different social settings, and self-perception of their proficiency in Basque and Spanish). The most relevant social factor for this study pertains to their self-reported use of Basque in different social domains $1-5$ Likert scale ( $1=$ not at all, $5=$ always). The differences between both groups are outlined in Table 1.

TABLE 1 Distribution of participants according to bilingual type and dialect type.

\begin{tabular}{|c|c|c|c|c|c|c|}
\hline & \multicolumn{4}{|c|}{ Basque-Spanish Bilinguals } & \multirow{2}{*}{\multicolumn{2}{|c|}{$\begin{array}{l}\text { Basque-French } \\
\text { bilinguals } \\
\text { Native Bilinguals }\end{array}$}} \\
\hline & \multicolumn{2}{|c|}{ Native Bilinguals } & \multicolumn{2}{|c|}{$\begin{array}{l}\text { Early Sequential } \\
\text { Bilinguals }\end{array}$} & & \\
\hline Speaker count & $\mathrm{N}=42$ & & $\mathrm{~N}=15$ & & $\mathrm{~N}=15$ & \\
\hline \multirow[t]{2}{*}{ Dialect } & \multicolumn{2}{|c|}{ Gernika Basque } & \multicolumn{2}{|c|}{ Standard Basque } & \multicolumn{2}{|c|}{ Lapurdi Basque } \\
\hline & $\operatorname{Mean}(\mathrm{SD})$ & range & Mean (SD) & range & $\operatorname{Mean}(\mathrm{SD})$ & range \\
\hline Age & $40.7(6.1)$ & $18-65$ & $26.2(3.7)$ & $18-31$ & $25.2(4.3)$ & $18-40$ \\
\hline $\begin{array}{l}\text { Age of Acquisition } \\
\text { (Basque) }\end{array}$ & $0.9(0.3)$ & $0-2$ & $3.5(0.4)$ & $3^{-5}$ & $0.7(0.2)$ & $0-2$ \\
\hline Use of Basque & $4.1(1.3)$ & $1-5$ & $2.2(0.8)$ & $1-5$ & $3.4(2.1)$ & $1-5$ \\
\hline
\end{tabular}




\subsection{Linguistic Factors}

The focus of the present study is to examine the use of DoM both in speakers' Basque and Spanish. All data were manually transcribed using the linguistic annotator ELAN (Sloetjes and Wittenburg, 2008). Following Comrie's (2011) approach to argument alignment, prototypical two-place predicate verbs (or verbs that are used transitively) were annotated for the presence of a direct object that is either marked with canonical absolutive or dative (DOM). Many of the verbs extracted à la Comrie (2011) also included the so-called bivalent unergatives or alternating verbs (deitu 'to call'). Because these verbs have been shown to syntactically behave differently from true DoM instances in Basque (Fernández and Rezac, 2016; Odria, 2014, 2017), Basque alternating verbs (deitu 'call', begiratu 'to look at', langundu 'to help') were excluded from the present analysis. Impersonal sentences (ikusten da 'it is seen' or defendidu ein bier da [euskerie] 'Basque needs to be defended') were also excluded because they resemble Spanish se le constructions analyzed in Ormazabal and Romero (2007), which behave as indirect objects in Basque (Fernández and Ortiz de Urbina, 2012). Finally, lexicalized expressions were also excluded as these are processed differently and do not denote true Dом constructions. Such expressions included bilatzen bazu, ezu topaten 'if you look for it, you won't find it', ikusiko dugu 'we will see', ikustenzu? 'you see?').

We adopted the principle of accountability couched within the sociolinguistics tradition (Labov, 1972) and coded for the possible linguistic environments in which DOM could occur based on five linguistic factors that pertain to the semantics of the DP (ANIMACY, SPECIFICITY, PERSON, NUMBER, NULL OBJECTS) and three factors pertaining to the verb (VERB_SEMANTICS, TENSEASPECT-MOOD, VERB_BORROWING).

The four main DP factors ANIMACY_SPEC_PERSON_Number were collapsed into one linguistic factor in order to avoid collinearity effects (Zurr et al., 2010). Because there were very few nonhuman animate objects (animals), these were excluded from the data and only human and non-animate objects were included. Also, second person plural objects were not produced; Hence, this factor yielded 12 levels: (1) first person singular, (2) first person plural, (3) [+spec] second person singular, (4) [-spec] second person singular, (5) [+human] [+ spec] third person singular, (6) [+human $][+$ spec $]$ third person plural, (7) [+human][-spec] third person singular, (8) [+human][-spec] third person plural, (9) [-human][+ spec] third person singular, (10) [-human][+ spec] third person plural, (11) [-human][-spec] third person singular and (12) [-human] [-spec] third person plural. Following Austin (2006) the DP was also coded in terms of nullness, that is, whether the DP was overt or null. 
Regarding VERB_SEMANTICS, target tokens were classified into seven verb types according to the semantic field that they belong to (Etxepare, 2003; Levin, 1993): (1) behavioral (zigortu 'to punish'; hartu 'to hire'), (2) physical (altxatu 'to lift'; harrapatu 'to catch'), (3) motion (eraman 'to take/carry'; bidali 'to send'), (4) perceptual (ikusi 'to see'; entzun 'to hear') and (5) psychological (maitatu 'to love'; ezagutu 'to know'). It has been shown that certain verbs favor Dом because they mainly govern animate objects (Fernández-Ordóñez, 1999; Montrul, 2004).

Regarding Tense-Aspect-Mood (TAM), studies on Basque Dом (Fernández and Rezac, 2016) have shown that Basque Dom is more likely in past tensed forms. In order to understand whether this trend holds true in Gernika Basque and Standard Basque, we coded this factor as: (1) present tense (ikusten zaittu dotzut 'I see you'); (2) present perfect (ikusi zaittut dotzut 'I have seen you'); (3) past simple (ikusi zaitteten notzun 'I saw you'); (4) past imperfect (ikusten zaittuten $\sim$ notzun 'I used to see you'); (5) conditional (ikusi(-ten) bazaittuten badotzuten 'if I see you') and (6) future (ikusiko zaittut $\sim$ dotzut 'I will see you'). If Gernika Basque and Standard Basque conform to the previous literature, it is expected that past tense forms will favor Basque DOM more so than present tense forms.

The last linguistic factor that was considered is if the verb is a borrowing from Spanish. This factor was chosen following Heine and Kuteva (2010), who suggest that when a grammatical structure is borrowed from one language to another, it often times enters through the semantics of the verb. Therefore, it is hypothesized that when Basque bilinguals borrow a Spanish verb that encodes animate human direct objects with dative, this might favor the use of DOM in Basque. These verbs include the Basque verbs: ikusi 'to see', atara 'to take out', ezagutu 'to know/meet', hartu 'to grab', entzun 'to hear/listen'. Verbs borrowed from Spanish include: atendidu 'assist', aburridu 'to bore', inbitatu 'to invite', amenazatu 'to threaten', obligatu 'to oblige'. In order to determine whether verbs were borrowed from Spanish or were considered Basque, the verbs produced by speakers were checked in the Basque etymological dictionary of Basque, or Orotariko Euskal Hiztegia, composed by the Basque Academy. This dictionary gathers information about the first attested uses of each verb. If the verb is classified as prototypical Basque (such as ikusi 'to see'), this verb was classified as Basque. On the contrary, if the verb had a romance etymology and was attested prior to the 1920s, it was considered a borrowed verb (obligatu = Spanish obligar 'to oblige').

The Spanish data was coded according to the variability found in the case of DO clitic forms, which only occur with third person forms. The dependent 
variable was case: whether they appear in accusative $l o(s) / l a(s)$ or dative $l e(s)$. For Spanish, five linguistic factors were considered: ANIMACY (human vs. nonanimate), NUMBER (singular vs. plural), GRAMMATICAL GENDER (femenine vs. masculine), VERB_SEMANTICS and TAM. This last factor was coded following the same classification for Basque as explained above.

\section{$6 \quad$ Results}

\subsection{Distribution of Data: Basque Doм and Basque-Spanish Leísmo}

For the Basque data set, there was a total of 2,473 transitive constructions produced. Because all Dом tokens appeared when the object was animate, the probability of ром usage was calculated out of the possible animate objects produced. In that respect, Table 2 shows that GB speakers produced 608 sentences with animate direct objects (DO), SB speakers produced only 170, and Baiona speakers produced 247 tokens, suggesting that constructions of animate DOs are less common (41.4\%) than with non-animate DOs. Our frequency data show that GB speakers produced $36.8 \%$ of DO animate objects with dative as opposed to a $16.5 \%$ among SB speakers and $2 \%$ among Basque-French bilinguals. With respect to Spanish, the token distribution was even lower, ${ }^{10}$ but the overall use of leismo was much higher in the Gernika and Bilbao groups (93.8\% and 81.1\%, respectively). These results show that Basque Dom, albeit with some individual tokens, ${ }^{11}$ is restricted to Basque-Spanish bilinguals.

We also examined whether Basque ром appears in finite and non-finite clauses and whether the dative case in the NP agrees in the auxiliary in finite clauses. Table 3 shows the distribution of produced Basque Dом according to finiteness and agreement in the Basque data. Results show that although Basque Dом appears both in finite and non-finite clauses, most of the tokens were produced in finite ones, and it was consistent across all three groups. Importantly, all finite clauses show agreement; that is, when dative appeared in the NP it also appeared in the auxiliary verb.

10 The low rates of third person clitics probably have to do with the fact that third person objects are not common in natural speech (Balasch, 2011; Tippets, 2011).

11 As explained in Rodríguez-Ordóñez (2016:162-164), and in accordance with Oyharzabal, et al. (2011), the few tokens of Basque Dом in Lapurdi Basque were attributed to potential dialectal contact of Basque, whereby these speakers may have acquired some sort of Basque DOM from their parental input, who are originally from DOM-speaking areas. 
TABLE 2 Distribution of Dом in Basque and Basque-Spanish leísmo across groups.

\begin{tabular}{|c|c|c|c|c|c|}
\hline & \multicolumn{4}{|c|}{ Basque-Spanish Bilinguals } & \multirow{3}{*}{$\begin{array}{l}\text { Basque-French } \\
\text { bilinguals } \\
\text { Native bilinguals } \\
\text { (Lapurdi Basque) } \\
\text { Basque }\end{array}$} \\
\hline & \multicolumn{2}{|c|}{$\begin{array}{l}\text { Native bilinguals (Gernika } \\
\text { Basque) }\end{array}$} & \multicolumn{2}{|c|}{$\begin{array}{l}\text { Early sequential Bilinguals } \\
\text { (Standard Basque) }\end{array}$} & \\
\hline & Basque & Spanish & Basque & Spanish & \\
\hline $\begin{array}{l}\text { Canonical } \\
\text { case-marking }\end{array}$ & $\begin{array}{l}384 \\
(63.2 \%)\end{array}$ & $\begin{array}{l}9 \\
(6.2 \%)\end{array}$ & $\begin{array}{l}142 \\
(83 \cdot 5 \%)\end{array}$ & $\begin{array}{l}10 \\
(18.9 \%)\end{array}$ & $\begin{array}{l}242 \\
(98 \%)\end{array}$ \\
\hline DOM/leísmo & $\begin{array}{l}224 \\
(36.8 \%)\end{array}$ & $\begin{array}{l}136 \\
(93.8 \%)\end{array}$ & $\begin{array}{l}28 \\
(16.5 \%)\end{array}$ & $\begin{array}{l}43 \\
(81.1 \%)\end{array}$ & $\begin{array}{l}5 \\
(2 \%)\end{array}$ \\
\hline Total & 608 & 145 & 170 & 53 & 247 \\
\hline
\end{tabular}

TABLE 3 Distribution of DOM in Basque according to finiteness and agreement.

\begin{tabular}{|c|c|c|c|}
\hline & \multicolumn{2}{|c|}{ Basque-Spanish Bilinguals } & \multirow{2}{*}{$\begin{array}{l}\text { Basque-French } \\
\text { bilinguals } \\
\text { Native bilinguals } \\
\text { (Lapurdi Basque) }\end{array}$} \\
\hline & $\begin{array}{l}\text { Native bilinguals } \\
\text { (Gernika Basque) }\end{array}$ & $\begin{array}{l}\text { Early sequential } \\
\text { Bilinguals (Stan- } \\
\text { dard Basque) }\end{array}$ & \\
\hline \multicolumn{4}{|l|}{ Finite } \\
\hline NPDAT - AUXDAT & $62(27.7 \%)$ & $9(32.1 \%)$ & $2(40 \%)$ \\
\hline NPNULL - AUXDAT & $136(60.7 \%)$ & $15(53.6 \%)$ & $3(6 o \%)$ \\
\hline \multicolumn{4}{|l|}{ Non-finite } \\
\hline NPDAT & $26(11.6 \%)$ & $4(14.3 \%)$ & $\mathrm{o}(\mathrm{o} \%)$ \\
\hline Total & 224 & 28 & 5 \\
\hline
\end{tabular}

\subsection{Statistical Analysis}

In order to locate the internal structure of the variation regarding the use of Basque DO, a number of mixed-effects models were computed using the glmer function in the lme4 package in $R$ (Bates, et al., 2015). The first model included all the Basque data establishing ром (canonical vs. dative) as the 
dependent variable, and GROUP and five linguistic variables as fixed factors (ANIMACY_SPEC_PERSON_NUMBER, NULL OBJECTS, VERB_SEMANTICS, VERB_BORROWING and TAM). The second model was performed on the Spanish data including pronoun case (canonical vs. leísmo) as the dependent variable, and the following factors as fixed: GROUP, ANIMACY_SPEC, GRAMMATICAL GENDER, NUMBER, VERB SEMANTICS and TAM. In addition, SPEAKER and VERB ITEM were included in the model as random effects in order to neutralize the possibility of undue influence (e.g., extreme outliers) of particular individual speakers on the overall data-set. In identifying the best fitted model for the data, all nested models were compared using the function ANOvA and the most reliable model was chosen based on lowest AIC values. This analysis will allow us to locate the similarities and differences regarding both DOM systems.

In variationist sociolinguistics, it is well stablished that the structural variability is constrained by a set of linguistic factors with relative degrees of favorability. To determine the order in which these factors come about, we followed the hierarchy constraints analysis, which examines the relative favorability of a factor in predicting a linguistic variable (canonical vs. DOM) within each group (Walker, 2014:451). In studying variable contexts of DOM in Basque (and leísmo in Spanish), in each group further allows us to represent the variable grammar of each bilingual type; groups who share a hierarchical constraint are argued to share the same linguistic system in their production of Doм or leismo.

\subsection{Basque Dом}

Figure 1 shows the data for Basque ром in 3 dialects of Basque. The best fitted model for the Basque data set shows that the GB use more Basque DOM and the rest of the two groups, a difference that was statistically significant $(\beta=-0.014, z=-2.377, \mathrm{p}<0.02$; further Tukey post-hoc comparisons reveal that the differences between the Baiona group and the other two are also statistically significant $\beta=0.02733, z=4.115, \mathrm{p}<0.001 ; \beta=-0.04 .283, z=-6.547$, $\mathrm{p}<0.001$ ).

In terms of the linguistic factors, the step-wise ranking analysis showed that linguistic factors favoring D ом were ranked as follows: animacy_spec_person_ number $>$ verb semantics $>$ verb borrowings $>$ null objects $>$ TAM. This ranking suggests that the most important factor governing the use of Basque DOM animacy_spec_person_number followed by verb semantics verb borrowings, null objects and TAM. In order to locate whether this ranking holds constant for both groups, two models were created, one per group: native-bilinguals from Gernika and early sequential bilinguals from Bilbao. The same linguistic factors were considered and speaker was included as random effect. Table 4 


\section{Frequency Rates Basque DOM}

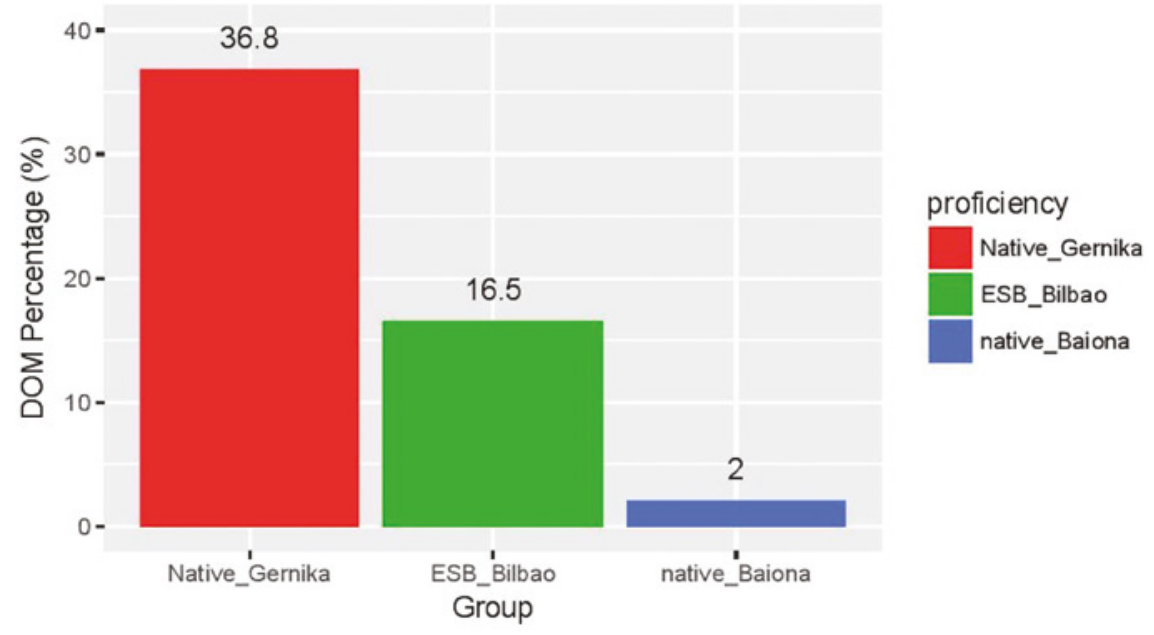

FIGURE 1 Frequency rates of Basque DOM

TABLE 4 Mixed effects model of the factors contributing to the use of Basque Dом in Gernika Basque (GB).

\begin{tabular}{|c|c|c|c|}
\hline & $\beta$ & $\mathrm{Z}$ & $p$ \\
\hline $\begin{array}{l}\text { Intercept } \\
\text { ANIMACY_SPEC_PERSON_NUMBER } \\
\text { (RL: first_sing) }\end{array}$ & -0.059 & -3.995 & $<.001 * * *$ \\
\hline First_PLURAL & 0.024 & 1.202 & 0.23 \\
\hline [+spec] Second_SINGULAR & 0.012 & 0.871 & 0.38 \\
\hline [+ spec] Third_sINGULAR & -0.064 & 5.420 & $<.001 * * *$ \\
\hline [+ spec] Third_PLURAL & -0.080 & 5.863 & $<.001 * * *$ \\
\hline [-spec] Second_SINGULAR & 0.031 & 1.643 & 0.10 \\
\hline [-spec] Third_sINGULAR & -0.087 & 5.223 & $<.001 * * *$ \\
\hline [-spec] Third_ PLURAL & -0.087 & $4 \cdot 549$ & $<.001 * * *$ \\
\hline \multicolumn{4}{|l|}{ VERB SEMANTICS (RL: perceptual) } \\
\hline $\begin{array}{l}\text { Behavioral (inbitatu 'to invite'; } \\
\text { kontratatu 'to hire') }\end{array}$ & 0.068 & 2.240 & $<.03 *$ \\
\hline $\begin{array}{l}\text { Physical (hartu 'to take'; jo 'to hit', } \\
\text { tiratu 'to pull') }\end{array}$ & 0.063 & 2.044 & $<.05 *$ \\
\hline
\end{tabular}


TABLE 4 Mixed effects model of the factors contributing to the use of Basque DOM (cont.)

\begin{tabular}{|c|c|c|c|}
\hline & $\beta$ & $\mathrm{Z}$ & $p$ \\
\hline \multicolumn{4}{|l|}{ VERB TYPE (RL: Basque) } \\
\hline Spanish borrowing & 0.021 & 1.984 & $<.05 *$ \\
\hline \multicolumn{4}{|l|}{ NULL OBJECT (RL: overt) } \\
\hline $\mathrm{NP}_{\mathrm{NULL}}$ & 0.011 & 1.967 & $<.05 *$ \\
\hline \multicolumn{4}{|c|}{ VERB TYPE*NULL (RL: Basque* overt) } \\
\hline Spanish borrowing*null & 0.029 & 2.942 & $<.01 * *$ \\
\hline \multicolumn{4}{|c|}{ TAM (RL:Present_conditional) } \\
\hline Present_simple & 0.067 & 2.820 & $<0.01 * *$ \\
\hline Present_perfect & 0.056 & 2.319 & $<.03 *$ \\
\hline Past_simple & 0.063 & 2.747 & $<0.01 * *$ \\
\hline
\end{tabular}

The estimated variance of the random intercept of SPEAKER is 0.8086 .

The estimated variance of the random intercept of VERB ITEM is 4.6541 .

shows the internal configuration of constraints with respect to their use of Basque DOM within the GB speakers:

The model showed that the linguistic factors favoring Gernik Basque Dом were ranked as follows: animacy_spec_person_number > verb semantics > verb borrowings $>$ null objects $>$ TAM, all being statistically significant. Beginning with the highest ranked factor (ANIMACY_SPEC_PERSON_NUMBER), the model showed that both First_-SING (reference level) and First_PL objects favor Basque DOM and these were not statistically significant $(\beta=0.024, z=1.202$, $p=0.23$ ). Second singular objects did not reach statistical difference with respect to first person objects, suggesting that second singular objects do not behave differently with respect to Gernika Basque Doм. This finding held true regardless of specificity as non-specific second person objects did not differ from specific ones. This is shown in (11a) and (11b) produced by the same speaker.

Gernika Basque

$\begin{array}{llllll}\text { (11) } a . & \text { es que } n i-k \text { uste } d \text {-o- } t & \text { ikusi } n \text {-o-tz-u-la } \\ \text { is that I-ERG think L-3SG.PRS-1SG.ERG } & \text { see 1SG.ERG-3SG.PAST-DF-2SG.DAT-REL }\end{array}$ 'So I think I saw you.' 
(11) b. ta gero aparte pilo bat afektetan d-o-tz-u- $\emptyset$ and then on.top.of lots one affect.PROG L-3SG.PRS-DF-2SG.DAT-3SG.ERG 'And then, on top of that, it affects you a lot.'

Results showed that the third person objects are the least favoring factor in GB $(20 \%)$, and that difference was statistically significant as compared to the reference level. Although results further show that third person (regardless of number and specificity) are statistically different from first person and second objects, Tukey post-hoc analysis shows that third person specific human objects are not statistically different from third person non-specific human ones $(\beta=-2.31, \mathrm{z}=-1.720, \mathrm{p}=0.6)$. However, a closer examination of the raw data (as displayed in table 5) shows that there are a handful third person specific objects with ром (21.1\% for singular, $8.6 \%$ for plural) whereas none of the nonspecific third person objects appear with DoM. Such lack of significance can be attributed to the nearly categorical use of DOM with first- and secondperson objects (ranging between $85.7 \%$ to $97.5 \%$ ) as well as to the low use of DOM with third person objects.

The second highest ranked factor was VERB_SEMANTICS and the model showed that both behavioral $(\beta=0.068, z=2.240, p<0.03)$ and physical verbs $(\beta=0.063, z=2.044, p<0.05)$ significantly favor Basque DoM with respect to the reference level (perceptual). The third most important constraint is verbal borrowings which shows a significant effect $(\beta=0.021, z=1.984, p<0.05)$, Spanish verbal borrowings favoring Basque DOM. The fourth factor in the ranking is null objects and the model showed that null objects strongly favor Basque DoM in GB $(\beta=0.011, \mathrm{z}=1.967, \mathrm{p}<0.05)$. Additionally, the model showed that

TABLE 5 Gernika Basque: Descriptive statistics for Basque DOM usage according to ANIMACY_SPEC_PERSON_NUMBER

\section{ANIMACY_SPEC_PERSON AND NUMBER DOM (n/N) DOM (\%)}

\begin{tabular}{lll}
\hline First_SINGULAR & $77 / 79$ & $97 \cdot 5 \%$ \\
First_PLURAL & $12 / 13$ & $92.3 \%$ \\
[+spec] Second_SINGULAR & $39 / 43$ & $90.7 \%$ \\
[+ spec] Third_sINGULAR & $46 / 219$ & $21.1 \%$ \\
[+ spec] Third_PLURAL & $6 / 70$ & $8.6 \%$ \\
[-spec] Second_SINGULAR & $12 / 14$ & $85.7 \%$ \\
[-spec] Third_sINGULAR & $0 / 69$ & $0 \%$ \\
[-spec] Third_PLURAL & $0 / 30$ & $0 \%$ \\
\hline
\end{tabular}


TABLE 6 Gernika Basque: Basque DOM according to null objects and verb type

$$
\text { Spanish borrowed verbs Basque verbs }
$$

$\begin{array}{lll}\text { Null } & 43 / 5^{2}(82.69 \%) & 92 / 185(49.79 \%) \\ \text { Overt } & 22 / 40(55 \%) & 38 / 260(14.62 \%)\end{array}$

there was an interaction between borrowed verbs and null objects $(\beta=0.029, z$ $=2.942, p<0.01$ ) suggesting that Basque DOM is more likely to occur when GB speakers borrow a verb from Spanish and the DP is null, a trend that is captured in the descriptive statistics in Table 6 and in example (12), whereby Dом appears with the verb amenaze 'to threaten' (Spanish amenazar).

Gernika Basque

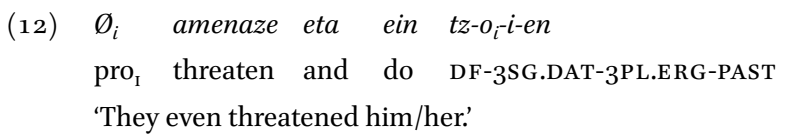

In terms of TAM, the model showed that present and past tenses are favoring Basque DOM in GB $(\beta=0.067, \mathrm{z}=2.820, \mathrm{p}<0.01 ; \beta=0.063, \mathrm{z}=2.747, \mathrm{p}<0.01)$. These results are consistent with other reported cases of Basque DOM. For instance, in Azpilkueta Basque, Basque DOM is restricted to past tenses (Yrizar, 1997). Similarly, Basque Dom seems to be obligatory in Araitz-Betelu Basque and optional in the present (Fernández and Rezac, 2016). Gernika Basque seems to pattern more closely to Lekeitio Basque, in which Basque Dом can be found both in the present and in the past.

Although the model did not show an interaction between ANIMACY SPEC_PERSON_NUMBER and Spanish borrowed verbs, the raw data shows an interesting trend worth noting. As shown in Table 7, DOM shows a categorical

TABLE 7 Gernika Basque: descriptive statistics for DOM usage according to verb BORROWINGS and GRAMMATICAL PERSON

\begin{tabular}{|c|c|c|}
\hline & Spanish borrowed verbs & Basque verbs \\
\hline First & $26 / 26(100 \%)$ & $63 / 66(95 \cdot 45 \%)$ \\
\hline Second & $20 / 20(100 \%)$ & $31 / 37(83.78 \%)$ \\
\hline [+spec] Third & $19 / 35(54.29 \%)$ & $33 / 254(12.99 \%)$ \\
\hline
\end{tabular}


use with first and second objects with Spanish borrowed verbs, and nearly categorically marked with dative in Basque verbs. In terms of the specific third person objects, more than half of these objects are being marked with the dative if the verb is borrowed from Spanish, whereas a small amount of them get marked with dative if the verb is Basque. The fact that Dom is more common in third person objects when the verb is borrowed from Spanish provides further evidence that Basque Dом is the result of contact with Spanish and that Basque began adopting DOM through verbal borrowings (Monoule, 2012).

The results for SB speakers (early sequential bilinguals), the model showed that not all linguistic factors are operative. The only relevant factor governing the use of Basque DOM in Standard Basque was ANIMACY_SPEC_PERSON_ NUMBER. The statistically significant results are shown in Table 8 .

The model showed that only specific $3^{\text {rd }}$ person singular objects significantly differed from the reference level whereas plural forms differed marginally. These results suggest that third person singular objects are less likely to be DoM-marked than plural ones, as evidenced in the descriptive statistics in Table 9 .

These results partially confirm the results obtained from Basque-Spanish native bilinguals from Gernika in the sense that first person objects are the ones that most favor Basque Dом. Even if that is the case, the rate at which Dом happens in the first person in within Standard Basque speakers is much

TABLE 8 Mixed effects model of the factors contributing to the use of Basque DOM in Standard Basque.

\begin{tabular}{lcll}
\hline & $\beta$ & $\mathrm{Z}$ & $\boldsymbol{p}$ \\
\hline $\begin{array}{l}\text { Intercept } \\
\text { ANIMACY_SPEC_PERSON_NUMBER } \\
\text { (RL: first_Sing) }\end{array}$ & 0.004 & 0.009 & 0.99 \\
[+spec] second_SINGULAR & & & \\
[+ spec] Third_SINGULAR & 0.012 & 1.413 & 0.16 \\
[+ spec] Third_PLURAL & 0.026 & 3.492 & $<.001 * * *$ \\
[-spec] Second_SINGULAR & 0.017 & 1.941 & 0.06 \\
[-spec] Third_SINGULAR & 0.002 & 0.002 & 0.99 \\
[-spec] Third_PLURAL & 0.002 & 0.009 & 0.99 \\
\hline
\end{tabular}

The estimated variance of the random intercept of SPEAKER is 0.1438 .

The estimated variance of the random intercept of VERB is 1.9174. 
TABLE 9 Standard Basque: DOM according to ANIMACY_SPEC_PERSON_NUMBER:

\section{ANIMACY_SPEC_PERSON AND NUMBER DOM (n/N) DOM (\%)}

$\begin{array}{lll}\text { First_SINGULAR } & 12 / 14 & 53.84 \% \\ \text { First_PLURAL } & \text { N/A } & \text { N/A } \\ \text { [+spec] Second_SINGULAR } & 4 / 13 & 30.77 \% \\ \text { [+ spec] Third_sINGULAR } & 6 / 84 & 7.14 \% \\ \text { [+ spec] Third_PLURAL } & 4 / 18 & 22.22 \% \\ \text { [-spec] Second_SINGULAR } & 0 / 1 & 0 \% \\ \text { [-spec] Third_sINGULAR } & 0 / 21 & 0 \% \\ \text { [-spec] Third_PLURAL } & 0 / 7 & 0 \%\end{array}$

TABLE 10 Early Sequential bilinguals: Basque DOM according to null objects and verb borrowings

\section{Spanish borrowed verbs Basque verbs}

\begin{tabular}{lll}
\hline Null & $2 / 8(25 \%)$ & $14 / 56(25 \%)$ \\
Overt & $2 / 12(16.67 \%)$ & $10 / 94(10.64 \%)$ \\
\hline
\end{tabular}

lower than in the Gernika group. Similar results are obtained with respect to specific and non-specific forms. Although the Tukey post-hoc comparisons did not show any statistical difference between third person specific and nonspecific forms $(\beta=-0.015, z=-0.008, p=1)$ the frequency data show that none of the non-specific forms were marked with dative, possibly confirming that Standard Basque ром is also restricted (beyond first and second person) to specific third person forms. Although the model did now show any other statistically significant results, the descriptive statistics in Table 10 provide two interesting trends: 1) Standard Basque speakers borrow less verbs than Gernika Basque but 2) they produce more DOM when the object is null.

Among the 20 verbs that were borrowed, 10 of them (50\%) were psychologi$\mathrm{cal}^{12}$ such as kabreatu (sp = cabrear) 'to make someone angry', sorprenditu

12 Its correspondent Basque verbs (haserretu 'to get angry'; harritu 'to get surprised') constitute the preoccupare-class (Belletti and Rizzi, 1988; Pesetsky, 1995) which in Basque are considered the transitive-intransitive psych verbs, alternating the ergative-absolutive or absolutive case-marking (Etxepare, 2003). The dative marking of the experiences in ${ }_{13}(\mathrm{a}-\mathrm{c})$ are evidence of Basque Dом, which are triggered by the use of leísmo in these verbs in Basque Spanish. 
( $\mathrm{sp}=$ sorprender) 'to surprise', inpaktatu $(\mathrm{sp}=\text { impactar), flipatu ( } \mathrm{sp}=\text { flipar })^{\text {'to }}$ flip, shock'. Among these verbs, only $4(20 \%)$ were produced with DoM, and these are shown in (13a-d):

Standard Basque

$\begin{array}{llllll}\text { (13) } & \text { Ni-ri } & \text { asko } & \text { kabrea-tzen } & d-i-t & \text { horr-ek } \\ & \text { I-DAT } & \text { a.lot } & \text { angry-PROG } & \text { L-1SG.DAT-3SG.ERG } & \text { that-ERG }\end{array}$ 'That angers me a lot.'

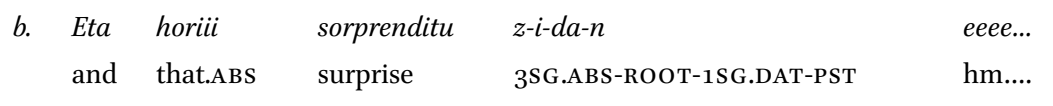

'And that surprised me hmm...'

(13) c. edo Estatu Batu-ez eeee sorprenditu z-i-da-n gauza handia or States United-INS hm.... surprise 3SG.ABS-ROOT-1SG.DAT-PST thing big 'And, about the United States hm..., the thing that surprised me the most...'

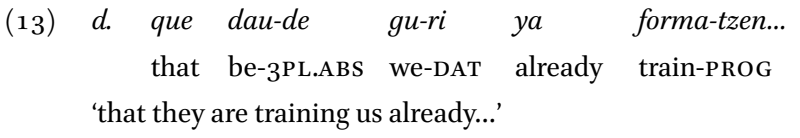

Finally, verb_semantics did not show statistical differences but the descriptive statistics show that SB speakers are similar to GB speakers in that they use more DOM with behavioral verbs (33.3\%) and physical verbs $(22.2 \%)$.

In summary, our statistical analyses show that the linguistic constraints affecting the use of Basque among Gernika Basque speakers and Standard Basque speakers are not exactly the same but show certain hierarchical patterns. The hierarchical constraints for Gernika Basque speakers were animacy_ spec_person_number $>$ verb semantics $>$ verb borrowings $>$ null objects $>$ TAM . whereas the hierarchical constraints for Standard Basque speakers was confined to animacy_spec_person_number. These results suggest that the mental representation of Basque Dом is different in these two populations and the borrowing mechanisms behind each group are different. Before we address this matter in the discussion section, we provide an analysis on the use of Spanish дом (through leísmo) among the Basque-Spanish bilinguals.

\subsection{Leísmo in Basque Leísta Dialect (BLD)}

Figures 2 and 3 show the distribution of leismo in terms of animacy and grammatical gender in Gernika and Bilbao. The best fitted model for the Spanish data shows that there was a main effect of GROUP $(\beta=-0.016, z=-2.921$, 


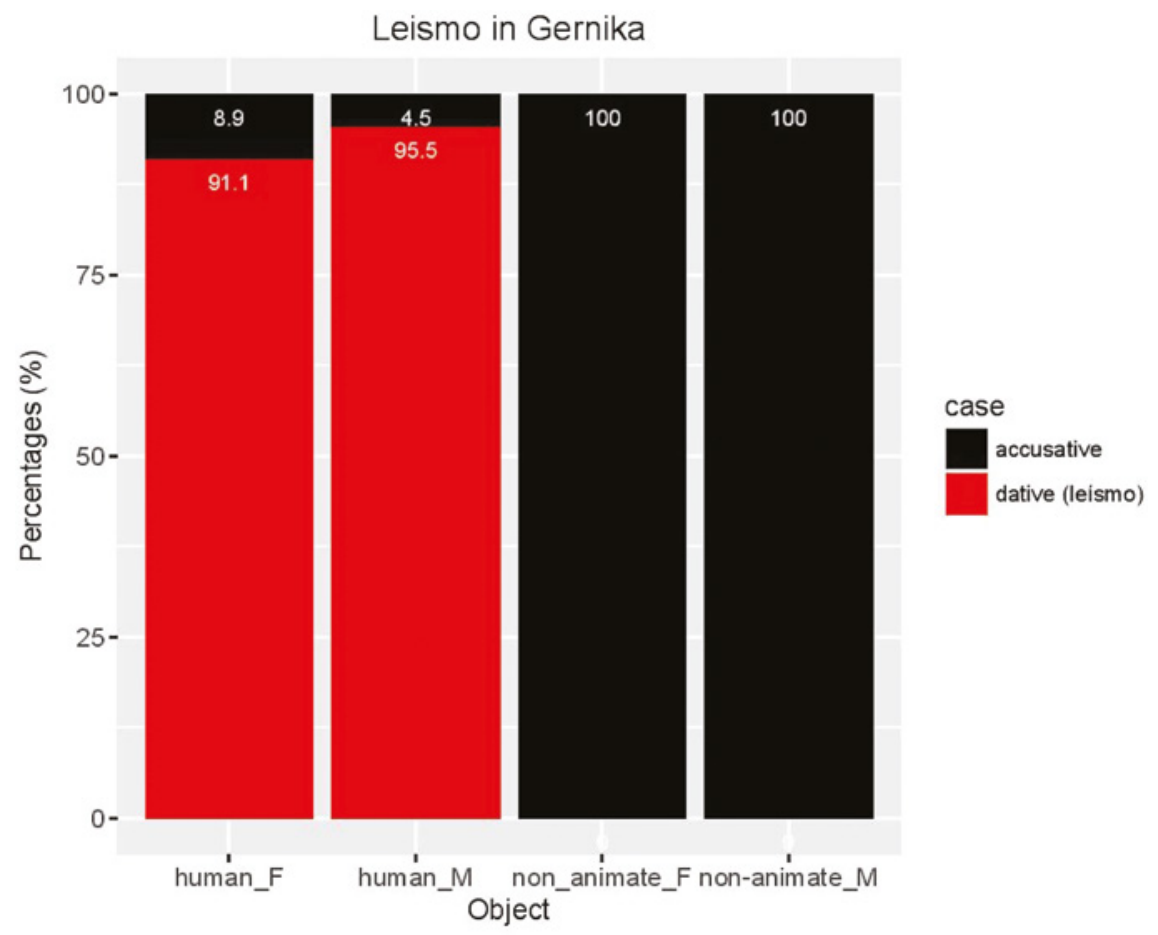

FIGURE 2 Leísmo in Gernika

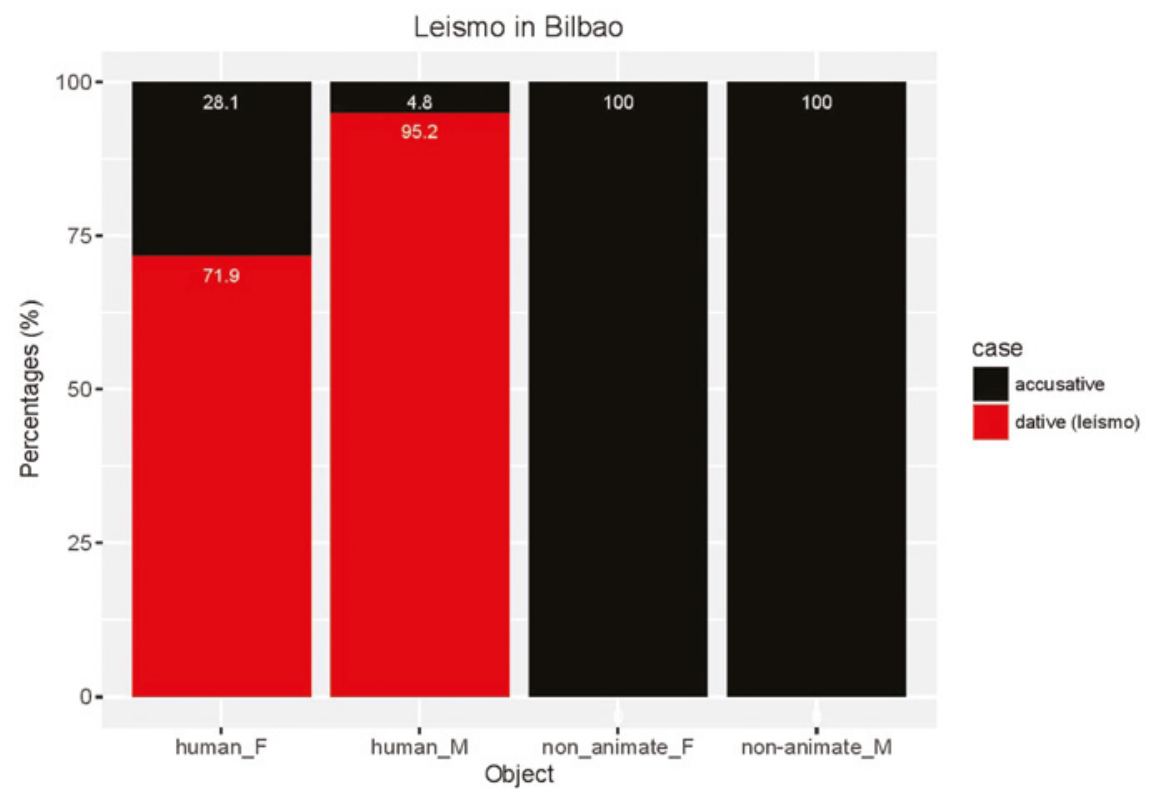

FIGURE 3 Leísmo in Bilbao 
$p<0.01)$ demonstrating that the use of leísmo is higher among Basque-Spanish bilinguals in Gernika (93.8\%) than those in Bilbao (77\%). The model showed no main effect of animacy $(\beta=-0.03, z=-0.002, p=0.99)$. This lack of significance is attributed to the fact that no variation was found within this factor as leismo is categorically restricted to animate objects among these speakers. There was a marginally significant effect in terms of grammatical gender $(\beta=$ 0.096, $z=1.825, p=0.06$ ), being masculine objects favoring leísmo. No other main effects were found. In terms of the hierarchy constraint, the factors favoring leismo are ranked as follows: animacy $>$ specificity $>$ TAM $>$ grammatical gender $>$ verb_semantics. The low amount of produced third person clitics in Spanish hinders a thorough statistical analysis for each group. For that matter, the comparative analysis between the use of leísmo in Gernika and Bilbao will heavily rely on descriptive statistics.

An important difference between both groups is that leismo is conditioned by animacy and gender in Bilbao, but not in Gernika. Examples showing leismo with both genders and numbers are shown in (14a-d) for the Gernika Group.

Basque Leísta Dialect (Gernika)

(14) a. y pues eee le conocí en la plaza (le = su novio) and so hmm 3SG.DAT.CL met in the plaza (le = her boyfriend 'And so hmm I met him in the plaza.'

(14) b. Yo le dije que le cogía al mes (le = Soraya) I 3SG.DAT.CL said that 3SG.DAT.CL took once month (le = Soraya $\left.{ }_{\mathrm{F}}\right)$ 'I told her that I would receive her once a month.'

(14) c. Ya estaban casaus yo cuando les conocí ya eran todo uno already were married I when 3PL.DAT.CL met already were all one 'They were already married, when I met them they were already one.'

(14) $d$. Yo les quiero mucho a mis amigas I 3PL.DAT.CL love much DOM my friends $\mathrm{F}_{\mathrm{F}}$ 'I love my (girl)friends very much.'

Although both groups are characterized by animate leismo (use of le with DO animate objects irrespective of grammatical gender) there is more variation in Bilbao: $4.8 \%$ of the human masculine objects were marked with accusative $l o(s)$ and $28.1 \%$ of the human feminine objects were marked with accusative $l a(s)$. Such variation is reflective of the heterogeneity of Spanish spoken in Bilbao. As mentioned in section 3, both Bilbao and Gernika experienced a great influx of Spanish monolinguals in the 196os, but such influx was greater 
in Bilbao. These Spanish monolinguals originally came from different territories from Castile and León, Extremadura, Andalusia and Galicia, where the use of leismo, if used, is restricted with animate masculine singular direct objects. Another possibility is that speakers in Bilbao may be orienting towards a Standard system, whereby leismo is mainly confined to masculine forms. In order to determine possibly dialect contact effects, we divided the data set into two categories: speakers whose both parents emigrated from territories outside of the Basque country and speakers whose parents are speakers of the Basque Leísta Dialect (for having been born and raised in the Greater Bilbao Area or in Gernika). ${ }^{13}$ Results in figures 4 and 5 show that in effect, the use of leísmo is conditioned by parental origin in Bilbao, but not in Gernika. These results suggest that the use of leísmo is more extended in Gernika irrespective of parental origin, whereas in Bilbao, a potential dialect contact contributes to the variation with respect to the use of leísmo (or lack thereof).

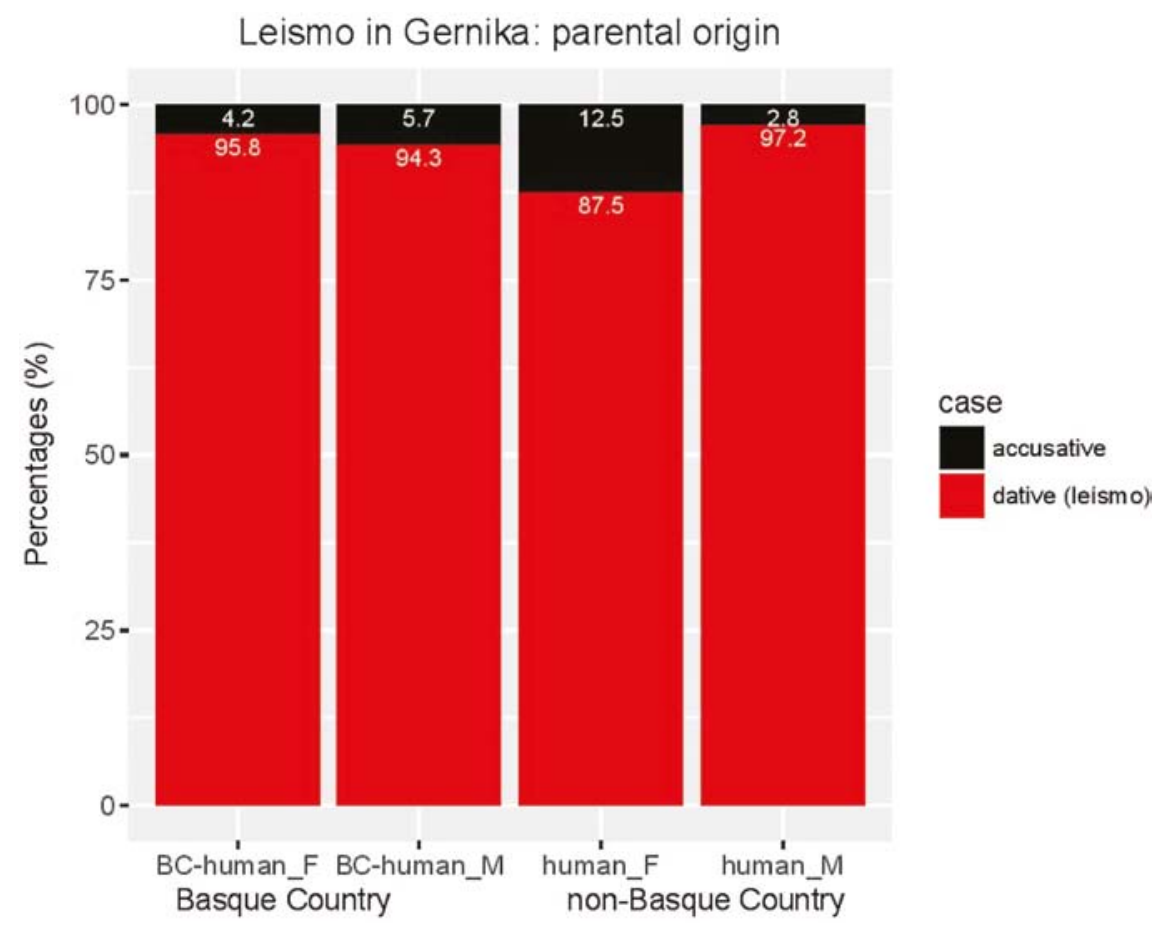

FIGURE 4 Leísmo in Gernika according to parental origin

\footnotetext{
13 There were seven speakers in Bilbao whose parents were raised outside of the Basque Country and eight whose parents were born and raised in Bilbao. For the Gernika group, there were nine speakers whose parents were from outside of the Basque Country and 33 whose parents were born and raised in the Basque Country.
} 


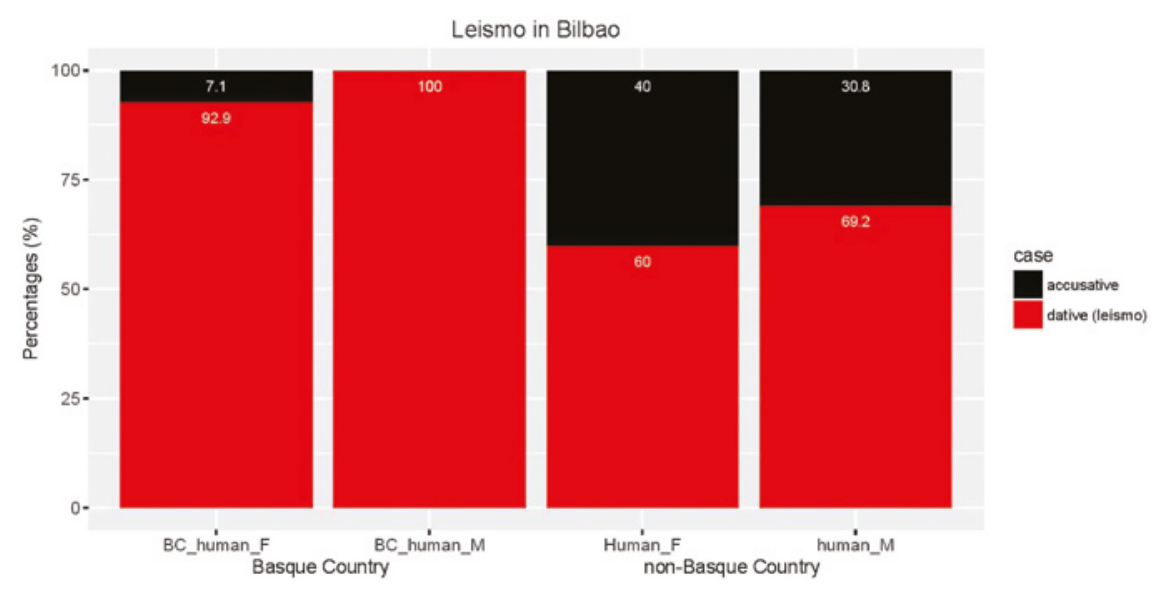

FIGURE 5 Leísmo in Bilbao according to parental origin

TABLE 11 Use of leísmo according to verb semantics in Gernika and Bilbao

\begin{tabular}{lll}
\hline & Gernika & Bilbao \\
\hline VERB SEMANTICS & Leísmo (\%) & Leísmo (\%) \\
Behavioral (coger 'to take') & $100 \%$ & $80 \%$ \\
Physical (agarrar 'to catch') & $100 \%$ & $81.3 \%$ \\
Perceptual (ver 'to see') & $94.1 \%$ & $81.8 \%$ \\
Psychological (conocer 'to know') & $89.7 \%$ & $73.7 \%$ \\
Motion (llevar 'to carry') & $87.5 \%$ & $71.4 \%$ \\
\hline
\end{tabular}

In terms of VERB SEMANTICS, Table 11 shows that all verb classes show very high rates of leismo, both in Gernika and Bilbao. Although little variation is shown across verb classes, especially among speakers in Gernika, a generalized trend is apparent: both behavioral and physical verbs are the two types of verb classes that categorically select leísmo in Gernika. The use of leísmo is also highest among these verb classes (as well as 'perceptual') in Bilbao. Psychological and motion verbs are less likely to select leísmo.

In summary, results for the oral production of leismo in Gernika and Bilbao show that leísmo is more extensive in Gernika, nearly achieving a categorical distinction between animate and non-animate objects, irrespective of parental origin. In Bilbao, the use of leismo is conditioned by parental origin, whereby its extended use is found among those whose parents are from the Basque country whereas those who have parents outside of the Basque country show 
lower rates of leísmo. In terms of VERB SEMANTICS, this factor contributed to a small amount of variation in the sense all verb classes showed high rates of leísmo but both behavioral and physical verbs are the leading ones in favoring leísmo.

\subsection{Leísmo and Basque DoM}

In order to demonstrate that animated leismo is affecting the use of Dом in Basque, we conducted a comparative analysis whereby we contrast the use of Basque Dом with speakers' use of leísmo with respect to group and dialect. Results are shown in Figures 6 and 7. Results show that even though the rates of leísmo and Dом do not equally match in their use, they do so in terms of relative frequency. Figure 6 shows that use of leismo is mostly frequent in the Gernika Group, regardless of parental origin. The same holds for Basque ром, as shown in figure 7 . Both the use of Basque ром and leísmo is lower among those speakers in Bilbao whose parents are not from the Basque Country. These results may suggest that the use of Basque Dом is conditioned by

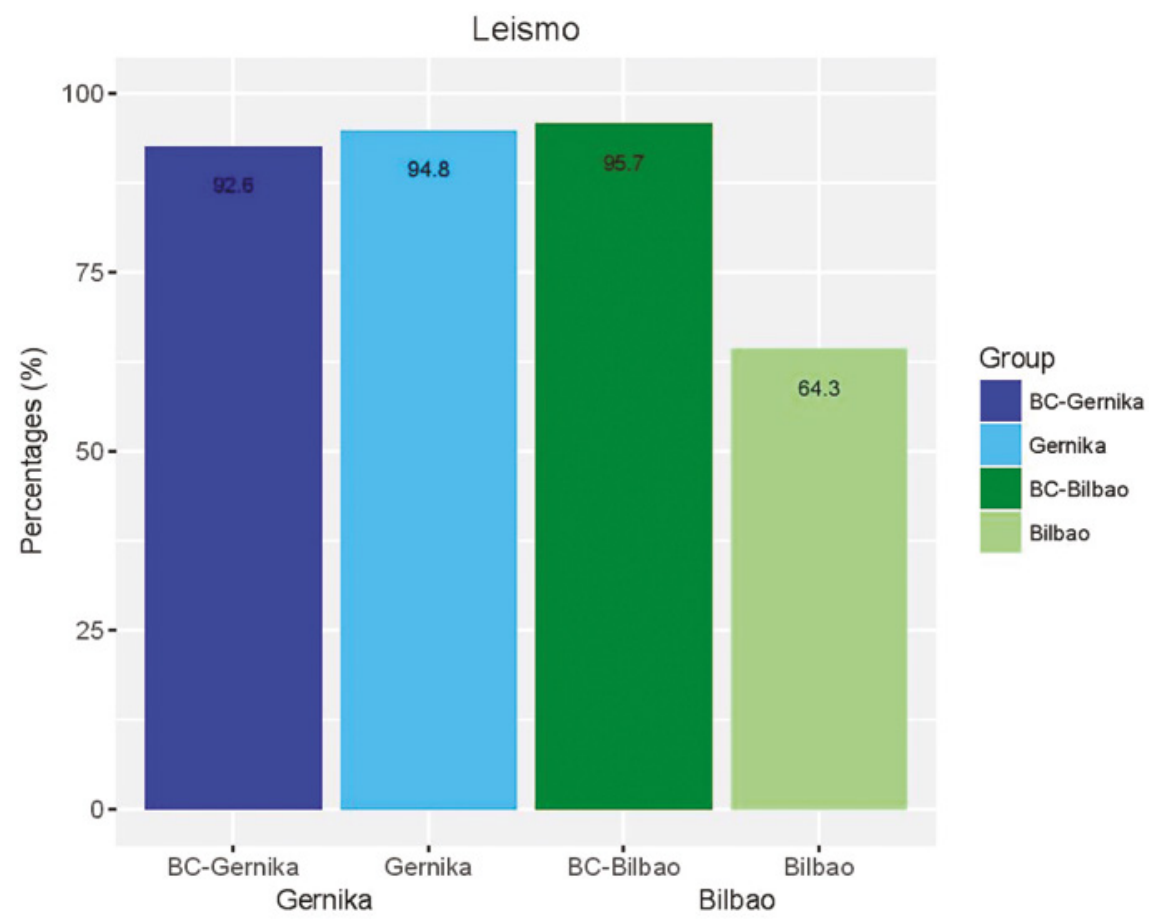

FIGURE 6 Leísmo in Gernika and Bilbao according to parental origin (BC-Gernika = Gernika speakers whose parents are from the Basque Country. BC-Bilbao = Bilbao speakers whose parents are from outside of the Basque Country) 


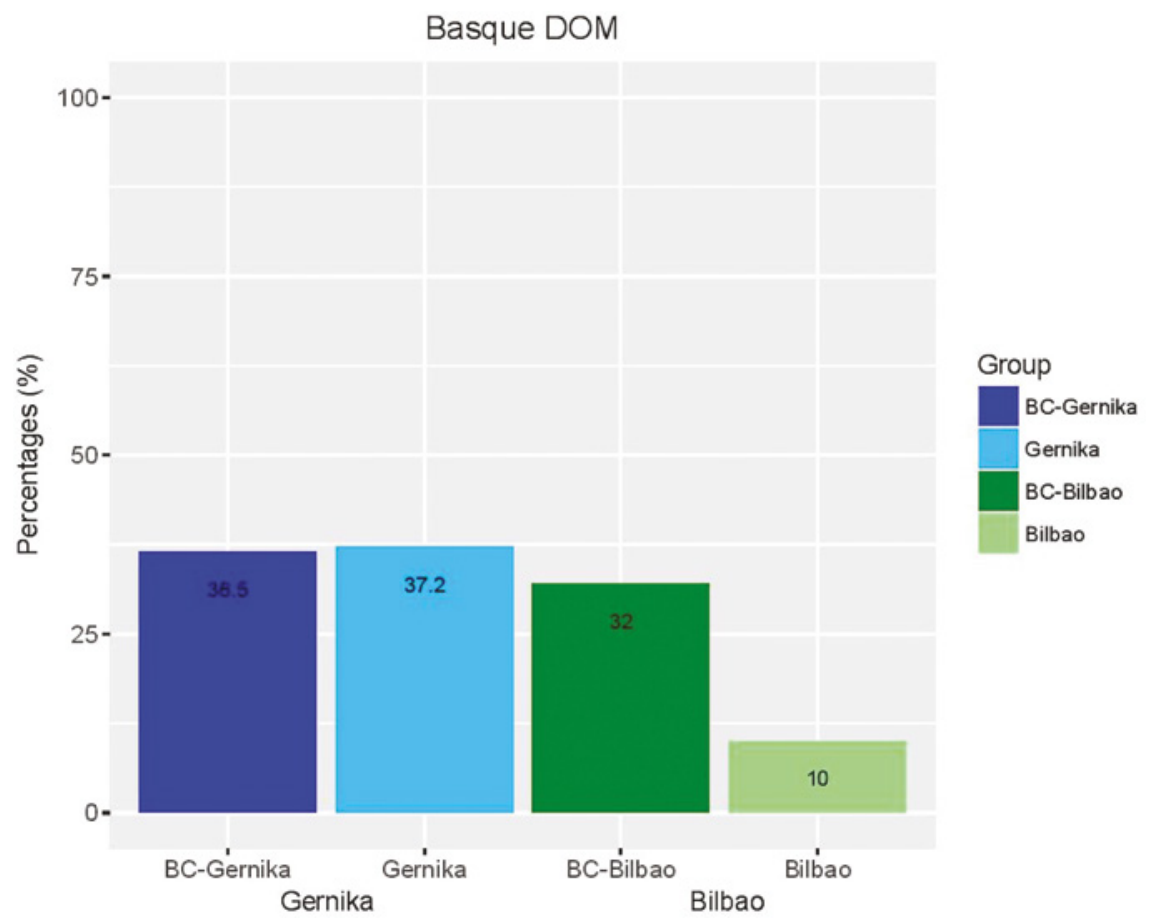

FIGURE 7 Basque DOM in Gernika and Bilbao according to parental origin (BC-Gernika = Gernika speakers whose parents are from the Basque Country. BC-Bilbao = Bilbao speakers whose parents are from outside of the Basque Country)

speakers' use of Basque-Spanish leísmo in that speakers showing higher rates of leísmo also show higher rates of Basque Dom.

The mail goal of the present paper was to determine the contact-induced mechanisms that have given rise to the variable use of Basque Doм. Our examination of the use of Basque DOM in the regional variety of Gernika Basque in comparison to the newly standardized variety Standard Basque shows that these populations employ different mechanisms in their use of Doм. Despite their differences, it is argued that Basque Dом does not constitute an example of syntactic borrowing. As such, we argue that the lack of direct borrowing as well as the variation found within the two varieties of Basque studied here involve a more complex process that can be captured by Heine and Kuteva's $(2005,2010)$ framework of replica grammaticalization, in which the borrowing 
of structural material may occur through matter borrowing, pattern borrowing or both.

As mentioned in section 2, multiple definitions have been used to describe processes such as 'borrowing', many of which define it in broader terms as the 'incorporation of foreign features' (Thomason, 2001:37). Such broad sense of borrowing has been criticized for being 'far from specific' (Heine and Kuteva, 2005:4). This is because speakers rarely borrow the exact same structure from the model language, but instead this process involves a replication whereby speakers transfer some material from the model language into the replica language using 'formulas of equivalence' (Kessing, 1991) and then adapt such material to the communicative needs of the speakers. It is precisely this lack of exact match between Basque Dом and the Basque Leísta Dialect which suggests that Basque Dом is involved in a replica grammaticalization.

Leismo only affects third person animate and specific objects, whereas in Basque ром, third person objects favor ром to a lesser degree than first and second. Another quantitative difference resides in the feature of VERB SEMANTICS. Although both groups conform to the leismo trends from Spanish in favoring Basque Dом in the same type of verbs (behavioral and physical), the rate at which they occur are far from the same. We have also demonstrated that the use of Basque Dom increases significantly in the third person when verbs are borrowed (at least for Gernika Basque speakers), suggesting that leísmo does influence the use of Basque Dом. Such uses resemble the neutralization second person direct and indirect (accusative-dative) pronouns of Spanish, providing evidence that Basque-Spanish bilinguals use formulas of equivalence or equating a grammatical structure of the model language (Spanish) with the replica language (Basque).

The notion of structural equivalence is of great importance in the replication of such material for a theory of contact-induced grammaticalization. This is because in cases of contact-induced grammaticalization, formulas of equivalence may serve as the triggering point, or may change the directionality that the grammaticalization may occur. As such, replica grammaticalization is defined as a process in which 'speakers create a new use pattern [...] that is equivalent to a corresponding category in the model language' which involves using materials from the recipient language (Heine and Kuteva, 2005, 2010:89). The corresponding category for Basque DOM would be the use of Basque-Spanish leísmo+a-marking which is being replicated in Basque with the dative $-r i$ and the corresponding agreement affixes in the auxiliary verb. As such, it is argued that Basque Dом is the result of the incorporation of an additive use pattern of already existing forms: the already existing Basque dative case marker $-r i$ is 
developing a 'new' function (not necessarily new meaning) that imitates that of its donor, Basque-Spanish dative clitic le $(s)$.

The question then arises as to how speakers equate similar concepts in each language for a replica grammaticalization to occur. Our hierarchy constraint analysis shows that the rankings of the linguistic factors affecting the use of Basque Dом in Gernika Basque and Standard Basque are not exactly the same. These hierarchies are repeated in (15) and (16):

(15) Hierarchy constraint for Gernika Basque speakers:

ANIMACY_SPEC_PERSON_NUMBER > VERB SEMANTICS

$>$ VERB BORROWINGS * NULL OBJECTS > TAM

(16) Hierarchy constraint for Standard Basque speakers: ANIMACY_SPEC_PERSON_NUMBER

The most important factors governing the use of Basque DOM is ANIMACY SPEC_PERSON_NUMBER, particularly first and second person objects. A crucial difference between both groups is that Basque DOM is governed by more factors in GB than in SB. of particular interest is the weight that verbal borrowings and null objects play in the use of DOM in GB. Here we argue that the differences in Gernika Basque and Standard Basque speakers depends on whether the replication begins as matter borrowing (МАT-borrowing), pattern borrowing (PAT-borrowing) or a combination of both.

The fundamental distinction between MAT and PAT-borrowing was put forward in Matras and Sakel (2007) in order to establish how linguistic elements are affected by contact. On the one hand, MAT-borrowing is referred to the 'direct replication of morphemes and phonological shapes from a source language' (Matras and Sakel, 2007: 829). On the other hand, PAT-borrowing does not necessarily involve the transportation of phonological material, but rather, 'it is the patterns of distribution, of grammatical and semantic meaning, and of formal-syntactic arrangement at various levels (discourse, clause, phrase, or word) that are modelled on an external source' (Matras and Sakel, 2007:829830). Gernika Basque speakers were shown to use more Basque Dom when they borrowed verbs from Spanish and when the NP was null. The fact that these two factors significantly interact with each other is an example of MATborrowing, whereby Gernika Basque speakers borrow both phonological and semantic content from Spanish borrowings and begin grammaticalizing Basque ром following the argument structure of model verbs (BasqueSpanish leísmo). As such, they begin replicating the model (leísmo) which leads them to PAT-borrowing. This process is exemplified in (17): 
(17) Replica grammaticalization of Basque ром in Gernika Basque:

1. An item serves to activate the model language (borrowings verbs from Spanish that govern animate objects)

2. Thus, [+animacy] is inserted as an agreement encoder between argument and clitic

3. Reanalysis: null objects in Basque open a window to 'confuse' direct or indirect objects of those verbs

4. [+animate][+specificity] is recovered through AG R in the auxiliary verb

5. Dative marker starts to be introduced in the most neutralized contexts (first and second person clitics, always animate)

6. Dative case marker extends to third person

7. Dative case marker may begin to be used with Basque verbs with similar lexical/semantic content and argument structure

Steps 1-3 exemplify mental mechanisms that speakers in Gernika Basque go through in their realization of Basque DOM, and their output is represented in steps 4-7. Importantly, the first step is what is triggered by contact in this case, which serves as an anchoring point for the development of a grammaticalization process that is constrained by the clitic system in Spanish and the syntax of Basque. In the first stage, the semantics of borrowed verbs from Spanish get transferred into Basque (MAT-borrowing), which 'activates' the insertion of semantic features such as [+animacy] [+specificity] as agreement licensers. When the language allows pro drop, reanalysis occurs as the speaker may find more difficulties in establishing the syntactic function of the dropped object, especially if the object is animate. This is because direct and indirect animate clitics in BLD are syncretic. Because this syncretism is absolute for first- and secondperson objects, which are always animate, Basque DOM is first introduced in the most neutralized contexts replicating the function of the dative case marker (PAT-borrowing). As shown in tables 5 and 6, these two contexts reach $100 \%$ when the verb has been borrowed from Spanish and nearly categorical among Basque verbs, making Dом nearly obligatory with first- and second-person objects in Gernika Basque. Basque Doм then extends to third person objects, which are also transferred through Spanish verbal borrowing. Finally, Basque DoM extends to other Basque verbs with similar lexical/semantic content and facilitated by a similar argument structure (transitivity) (eraman 'to take/carry' and mobidu = Spanish mover 'to take/move').

Standard Basque speakers on the contrary, do not show indications of MATborrowing as their verbal borrowing from Spanish are very limited $(\mathrm{N}=20)$ and almost non-existent with respect to their use of Basque Dом $(\mathrm{N}=4)$. Instead, it is argued that Standard Basque speakers resort to PAT-borrowing by 
replicating the dative patterns from Spanish. The proposed replica grammaticalization process for Standard Basque speakers is represented in (18):

(18) Replica grammaticalization of Basque Dом in Standard Basque: An item serves to activate language $\mathrm{M}$ (= syncretic pronoun system in Spanish)

Dative marker starts to be introduced in the most neutralized contexts (first and second person clitics, always animate)

Dative case marker extends to third person

Like Gernika Basque speakers, Standard Basque speakers activate their process of grammaticalization through the model language, but the material engaged in such activation is different. Contrary to Gernika Basque speakers, Standard Basque speakers do not directly resort to the phonological material of Spanish verbs (MAT-borrowing), but to the functions of the clitic system in Spanish (PAT-borrowing) and further follow a path of grammaticalization. In this respect, the proposed mechanisms for the development of Basque ром in Gernika Basque and Standard Basque provide further support for the claim that both MAT and PAT-borrowing are not necessarily mutually exclusive (as it is the case for Gernika Basque) a fact that has been found for other languages (Law, 2014; Seifart, 2015).

The differences in the status of Basque Dом among the two bilingual groups can also be attributed to the depth of contact between Basque and Spanish. This is because in order for grammaticalization to occur, at least a generational transmission pattern needs to occur (Bruyn, 1996, 2008; Hopper and Traugott, 2003; Brinton and Traugott, 2005). It can be argued that the DoM patterns in Standard Basque are representative of early stages of a grammaticalization because these speakers constitute the second generation of Standard Basque speakers who, albeit not having acquired it through parental input, have been exposed to the language from early childhood (2-5 years old). These results also show that the patterns of use of Basque Dом among these different groups pertains to two different historical depths of contact with Spanish; while Basque Dом is an 'old' phenomenon in Gernika Basque (Kaiser et al., 2018), the use of Standard Basque Dом among early-sequential bilinguals is a quite recent one and the degree to which each dialect has developed the use of Basque Dом is possibly delimited by the time span that both languages have remained in contact.

A question that remains to be explored is why the early sequential bilinguals in the present study show such low rate of verbal borrowings. On the one 
hand, such fact can be attributed to the fact that this variety, in its spoken form, has not been in contact for long enough for such borrowings to occur. On the other hand, the Standard variety of Basque constitutes an 'organic' variety that was created based on a number of literary traditions (Hualde and Zuazo, 2007) in which contact features (loanwords) may be selected on an integration basis. Another important reason could be the frequency of use of the language itself; the Gernika speakers reported to use Basque in their extended networks whereas those in Bilbao had a much respective social contexts in which they used their language. Taking usage-based approaches to contact linguistics, one would expect to find a more advance stage of grammaticalization among those who use Basque the most, and possibly with linguistic material that is more frequent. We leave this endeavor for the future.

The role that social meaning plays in the grammaticalization process of Basque Dом should not be discarded either. Although it has been argued that social factors are secondary in processes of grammaticalization, there is ample evidence that linguistic ideologies are also responsible to the kinds of linguistic material that speakers may borrow and the social consequences behind such borrowing (Babel, 2018). Basque Dom has been subject to much metapragmatic commentary, with social meanings attached to it depending on 'who' uses it (Rodríguez-Ordóñez, 2013, 2020). Such commentaries are often about third person or second person objects, and never about first-person objects. This suggests that the social salience of Dом is linguistically and ideologically mediated. Additionally, the borrowing of 'foreign' material is often criticized for Standard Basque speakers than it is for speakers of a regional variety (Lantto, 2018). This could also explain why Standard Basque speakers rarely include Spanish verbs in their repertoires, and therefore, DoM.

In conclusion, the present study argues that Basque Dom constitutes an example of 'grammatical borrowing' at the expense of replicating material from Basque-Spanish leísmo. In other words, Basque has created an innovative structure by replicating the functions of leismo. Thus, the already existing Basque dative case marker $-r i$ has developed a 'new' function that imitates that of its donor, Basque-Spanish dative clitic le(s) by means of PAT-borrowing. It was also shown that such replication is facilitated via MAT-borrowing (verbal borrowings) within speakers of Gernika Basque. These results provide evidence that semantic and lexical borrowing contribute to the mechanisms of grammatical replication (Silva-Corvalán, 1995; Heine and Kuteva, 2010; Winford, 2010) and that grammaticalization and contact are not mutually exclusive, but work in interaction with each other (Heine and Kuteva, 2005, 2010). 


\section{Acknowledgements}

The author wishes to thank Alexandru Mardale and Petros Karatsareas for inviting me to contribute to this special issue. Special thanks to two anonymous reviewers and Ane Odria for their helpful comments on earlier versions of this article. All errors remain my own.

\section{List of Abbreviations}

$\begin{array}{ll}1= & \text { first person } \\ 2= & \text { second person } \\ 3= & \text { third person } \\ \text { ABS }= & \text { Absolutive } \\ \text { ACC }= & \text { accusative } \\ \text { DAT }= & \text { dative } \\ \text { DF }= & \text { dative flag } \\ \text { DOM }= & \text { differential object marking } \\ \text { ERG }= & \text { ergative } \\ \mathrm{F}= & \text { feminine } \\ \text { INS }= & \text { instrumental } \\ \text { L }= & \text { L-morpheme } \\ \text { LOC }= & \text { locative } \\ \text { M }= & \text { masculine } \\ \text { PART }= & \text { participle } \\ \text { PAST }= & \text { past tense } \\ \text { PL }= & \text { plural } \\ \text { PRO }= & \text { pronoun } \\ \text { PROG }= & \text { progressive } \\ \text { PRS }= & \text { present tense } \\ \text { REL }= & \text { relative } \\ \text { SG }= & \text { singular }\end{array}$

\section{References}

Aissen, Judith. 2003. Differential object marking: iconicity vs. economy. Natural Language and Linguistic Theory 21: 435-483.

Austin, Jennifer. 2006. Dative-overmarking in Basque: Evidence of Basque-Spanish contact. Euskalingua 9:136-145. 
Babel, Anna M. 2018. Between the Andes and the Amazon: Language and Social Meaning in Bolivia. Tucson: The University of Arizona Press.

Balasch, Sonia. 2011. Factors determining differential object marking within its domain of variation. In Jim Michnowicz and Robin Dodsworth (eds.), Selected Proceedings

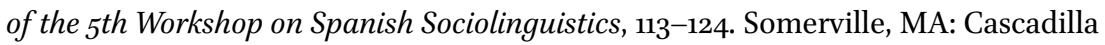
Proceedings Project.

Bates, Douglas, Martin Mächler, Ben Bolker and Steve Walker. 2015. Fitting Linear Mixed-Effects Models Using lme4. Journal of Statistical Software 67(1): $1-48$.

Belletti, Adriana and Luigi Rizzi. 1988. Psych Verbs and $\theta$-Theory. Natural Language and Linguistic Theory 6(3): 291-352.

Bossong, George. 1991. Differential object marking in Romance and beyond. In Dieter Wanner and Douglas A. Kibee (eds.), New analysis in Romance Linguistics: selected papers from the XVIII Linguistic Symposium on Romance Languages, 143-170. Amsterdam/Philadelphia:John Benjamins.

Bybee, Joan. 2008. Usage-based grammar and second language acquisition. In Peter Robinson and Nick C. Ellis (eds.), Handbook of cognitive linguistics and second language acquisition, 216-236. New York: Routledge.

Camacho, José, and Liliana Sánchez. 2002. Explaining clitic variation in Spanish. In Mengistu Amberber and Peter Collins (eds.), Formal approaches to language and universals and language variation, 21-40. Norwood: Ablex.

Campbell, Lyle. 1993. On proposed universals of grammatical borrowing. In Henk Aertsen and Robert J. Jeffers (eds.), Historical Linguistics 1989: Papers from the $9^{\text {th }}$ International Conference on Historical Linguistics 1989, 91-109.

Chomsky, Noam. 1993. A minimalist program for linguistic theory. In Ken Hale and Samuel J. Keyser (eds.), The view from Building 20: Essays in Linguistics in Honor of Sylvain Bromberger, ${ }^{-}{ }^{2}$. Cambridge, MA: MIT Press.

Chomsky, Noam. 200o. Minimalist inquiries: The framework. In Roger Martin, David Michaels Juan Uriagereka and Samuel J. Keyser (eds.), Step by step: Essays on Minimalist Syntax in Honor of Howard Lasnik, 89-155). Cambridge / London: MIT Press.

Coghill, Eleanor. 2014. Differential Object Marking in New-Aramic. Linguistics $5^{2}$ (2): 335-364.

Comrie, Bernard. 2011. Alignment of case marking of full noun phrases. In Matthew S. Dryer and Martin Haspelmath (eds.), The World Atlas of Language Structures Online. Leipzig: Max Planck Institute for Evolutionary Anthropology.

Croft, William. 2000. Explaining language change: An evolutionary approach. Harlow / New York: Longman.

DeMello, George. 2002. Leísmo in contemporary Spanish American educated speech. Linguistics 40(2): 261-283. 
Etxepare, Ricardo. 2003. Valency and argument structure in the Basque Verb. In José Ignacio Hualde and Jon Ortiz de Urbina (eds.), A grammar of Basque, 363-425. Berlin / New York: Mouton de Gruyter.

Etxepare, Ricardo, and Miriam Uribe-Etxebarria. 2012. Denominal necessity modals in Basque. In Urtzi Etxebarria, Ricardo. Etxepare and Myriam Uribe-Etxebarria (eds.), Noun phrases and nominalization in Basque, 283-330. Amsterdam: John Benjamins.

Eusko Jaurlaritza. 2013. V. Inkesta soziolinguistikoa. Vitoria-Gasteiz: Eusko Jaurlaritzaren Argitalpen Zerbitzu Nagusia.

Eusko Jaurlaritza. 2016. VI. Inkesta soziolinguistikoa: Euskal Autonomi Erkidegoa. Eusko Jaurlaritzaren Argitalpen Zerbitzu Nagusia.

Fernández, Beatriz and Milan Rezac. 2010. Datibo osagarri bitxiak eta datiboaren lekualdatzea: ari nai diyot eta kanta egin nauzu bidegurutzean. In Beatriz Fernández, Pedro Albizu and Ricardo Etxepare (eds.), Euskara eta euskarak: Aldakortasun sintaktikoa aztergai, 113-150. Vitoria-Gasteiz: EHU.

Fernández, Beatriz and Jon Ortiz de Urbina. 2012. Dative first complements in Basque. In Ernestina Carrilho and Beatriz Fernández (eds.), Syntactic microvariation in Westmost European Languages. Journal of Portuguese Linguistics (Special Issue), 83-98. Ediçoes Colibrí - Unviersidade de Lisboa.

Fernández, Beatriz, and Milan Rezac. 2016. Differential object marking in Basque varieties. In Beatriz Fernández and Jon Ortiz de Urbina (eds.), Microparameters in the Grammar of Basque, 93-138. Amsterdam: John Benjamins.

Fernández-Ordóñez, Inés. 1999. Leísmo, laísmo y loísmo. In Ignacio Bosque and Violeta Demonte (eds.), Nueva Gramática descriptiva de la lengua española, 1317-1398. Madrid: Espasa Calpe.

Fernández-Ordóñez, Inés. 2012. Dialect areas and linguistic change: Pronominal paradigms in Ibero-Romance dialects from a cross-linguistic and social-typology perspective. In Gunther de Vogelaer and Guido Seiler (eds.), The dialect laboratory. dialects as a testing ground for theories of language change, 73-106. Amsterdam: John Benjamins.

Franco, Jon. 1993. On object agreement in Spanish. PhD dissertation, University of Southern California, Los Angeles.

Gernikako Udala. 2002. Euskararen presentzia eta ausentzien diagnostikoa gernikalumon. Gernika: Gernikako Udala.

Hopper, Paul. J. and Sandra A. Thompson. 1980. Transitivity in grammar and discourse. Language $5^{6}$ (2): 251-299.

Haspelmath, Martin. 2005. Argument marking in ditransitive alignment types. Linguistic Discovery 3(1): 1-21.

Heine, Bernd and Tania Kuteva. 2005. Language Contact and Grammatical Change. Cambridge: Cambridge University Press. 
Heine, Bernd and Tania Kuteva. 2006. The Changing Languages of Europe. Oxford: Oxford University Press.

Heine, Bernd and Tania Kuteva. 2010. Contact and Grammaticalization. In Raymond Hickey (ed.), The Handbook of Language Contact, 86-105. Oxford: Wiley-Blackwell.

Hickey, Raymond. 2010. Language Contact: Reconsideration and Reassessment. In Raymond Hickey (ed.), The Handbook of Language Contact, 1-28. Oxford: WileyBlackwell.

Hualde, José Ignacio, Gorka Elordieta, and Arantzazu Elordieta. 1994. The Basque Dialect of Lekeitio. Bilbao / Donostia: University of the Basque Country.

Instituto Nacional de Estadística. 2016. [Last accessed July 2016], URL: http://www.ine. es/en/welcome.shtml.

Kessing, Roger M. 1991. Substrates, calquing and grammaticalization in Melanesian Pidgin. In Elizabeth E. Traugott and Bernd Heine (eds.) Approaches to Grammaticalization. Theoretical and methodological issues, 315-342. Amsterdam: John Benjamins.

King, Ruth. 2000. The Lexical Basis of Grammatical Borrowing: A Prince Edward Island French Case Study. Amsterdam and Philadelphia: John Benjamins.

Labov, William. 1972. Sociolinguistic patterns. Philadelphia: University of Pennsylvania Press.

Labov, William. 2001. Principles of Linguistic Change: Social Factors. London: Blackwell.

Landa, Alazne. 1995. Conditions on null objects in Basque Spanish and their relation to leísmo and clitic doubling. , University of Southern California.

Lantto, Hanna. 2018. New Basques and code-Switching: Purist tendencies, social Pressures. In Cassie Smith-Christmas, Noel Ó Murchadha, Michael Hornsby and Máiréad Moriarty (eds.), New speakers of minority languages: Linguistic ideologies and practices, $165^{-187}$. London: Palgrave Macmillan.

Law, Danny. 2014. Language Contact, Inherited Similarity and Social Difference: The Story of Linguistic interaction in the Maya Lowlands. Amsterdam/Philadelphia: John Benjamins.

Lefebvre, Claire. 1984. Grammaires en contact: définition et perspectives de recherche. Revue Québécoise de Linguistique 14:11-49.

Levin, Beth. 1993. English verb classes and alternations: A preliminary investigation. Chicago: University of Chicago Press.

Lightfoot, David. 1991. How to set parameters: Arguments from language change. Cambridge, MA: MiT Press.

Matras, Yaron. 1998. Utterance modifiers and universals of grammatical borrowing. Linguistics 36: 281-331.

Matras, Yaron. 2010. Contact, convergence, and typology. In Raymond Hickey (ed.), The Handbook of Contact Linguistics, 66-85. London: Blackwell. 
Matras, Yaron and Jeanette Sakel. 2007. Investigating the mechanisms of pattern replication in language convergence. Studies in Language 31 (4): 829-865.

McFadden, Thomas. 2004. The position of morphological case in the derivation: A study on the syntax-morphology interface. Ph.D. Dissertation, University of Pennsylvania.

Montrul, Silvina. 2004. Subject and object expression in Spanish heritage speakers: A case of morphosyntactic convergence. Bilingualism: Language and Cognition $7(2): 125^{-142 .}$

Mounole, Céline. 2012. The evolution of transitive verbs in Basque and emergence of dative-marked patients. In Gilles Authier and Katharina Haude (eds.), Ergativity and Voice, 355-380. Berlin / New York: Mouton de Gruyter.

Mougeon, Raymond, Terry Nadasdi and Katherine Rehner. 2005. Contact-induced linguistic innovations on the continuum of language use: The case of French in Ontario. Bilingualism: Language and Cognition 8 (2): 99-115.

Naes, Ashild. 2007. Prototypical transitivity. Amsterdam: John Benjamins.

Odria, Ane. 2014. Differential Object Marking and the nature of dative Case in Basque varieties. Linguistic Variation 14 (2): 289-317.

Odria, A. 2017. Differential object marking and datives in Basque syntax. Ph.D. Dissertation, University of the Basque Country.

Ormazabal, Javier and Juan Romero. 2007. The Object Agreement Constraint. Natural Language Linguistic Theory 25: 315-347.

Ormazabal, Javier and Juan Romero. 2013. Object clitics, agreement and dialectal variation. Probus 25 (2): 301-344.

Ortiz de Urbina, Jon. 1989. Parameters in the Grammar of Basque. Dordrecht: Foris.

Otheguy, Ricardo, Ana Celia Zentella, and David Livert. (2007). Language contact in Spanish in New York: Toward the formation of a speech community. Language 83: 770-802.

Oyharçabal, Beñat, Jasone Salaberria and Irantzu Epelde. (2011). Norantz datubasea: aurkezpena eta aditz-konmuztadurako datuak. Anuario Del Seminario De Filología Vasca Julio De Urquijo, 69: 1-38.

Palacios, Azucena. 2006. Cambios inducidos por contacto en el español de la sierra ecuatoriana: La simplificación de los sistemas pronominales (procesos de neutralización y elisión). Tópicos Del Seminario 15:197-229.

Pesetsky, David. 1995. Zero Syntax: Experiencers and Cascades. Boston: MIT Press.

Poplack, Shana and Stephen Levey. 2010. Contact-induced grammatical change: a cautionary tale. In Peter Auer and Jürgen Erich Schmidt (eds.), Language and Space An International Handbook of Linguistic Variation: Volume 1 - Theories and methods, 391-419. Berlin: Mouton de Gruyter.

Pylkkänen, Liina. 2002. Introducing arguments. Cambridge / London: the MIT Press. Roberts, Ian and Anna Roussou. 2003. A minimalist approach to grammaticalization. Cambridge: Cambridge University Press. 
Rodríguez-Ordóñez, Itxaso. 2013. Contact-induced phenomena in Gernika Basque: The case of dative over-marking. In Chad Howe, Sarah E. Blackwell and Margaret Lubbers Quesada (eds.), Selected Proceedings of the $15^{\text {th }}$ Hispanic Linguistics Symposium, 236-251. Somerville, MA: Cascadilla Proceedings Project.

Rodríguez-Ordóñez, Itxaso. 2016. Differential Object Marking in Basque: grammaticalization, attitudes and ideological representations. Ph.D. Dissertation, University of Illinois at Urbana-Champaign.

Rodríguez-Ordóñez, Itxaso. 2017. Reexamining Differential Object Marking as a linguistic contact-induced phenomenon in Gernika Basque. Journal of Language Contact $10(2): 318-352$.

Rodríguez-Ordóñez, Itxaso. 2020. The acquisition of Basque Differential Object Marking as a sociolinguistic variable. In Alexandru Mardale and Silvina Montrul (eds.), The acquisition of Differential Object Marking, 105-131. Amsterdam: John Benjamins.

Sankoff, Gilian. 2002. Linguistic outcomes of language contact. In Jack Chambers, Peter Trudgill, and Natalie Schilling-Estes (eds.), Handbook of Language Variation and Change, 638-668. Oxford: Blackwell.

Seifart, Frank. 2015. Direct and indirect affix borrowing. Language 91 (3): 511-532.

Silva-Corvalán, Carmen. 1998. On Borrowings as a mechanism of syntactic change. In Armin Schwegler, Bernard Tranel and Myriam Uribe-Etxebarria (eds.), Romance Linguistics: Theoretical Perspectives, 225-246). Amsterdam/Philadelphia: John Benjamins.

Silva-Corvalán, Carmen. 2008. The limits of convergence in language contact. Journal of Language Contact 2 (1): 213-224.

Sinnemäki, Kaius. 2014. A typological perspective on Differential Object Marking. Linguistics 52 (2): 281-313.

Sloetjes, Han and Peter Wittenburg. 2008. Annotation by category - ELAN and ISO DCR. In Proceedings of the 6th International Conference on Language Resources and Evaluation (LREC 2008).

Sportiche, Dominique. 1986. Clitic constructions. In Johan Rooryck and Laurie Zaring (Eds.), Phrase structure and the lexicon (pp. 213-276). Dordrecht: Kluwer.

Thomason, Sarah. G. 2001. Language Contact: An Introduction. Georgetown University Press.

Thomason, Sarah. G. 2010. Contact explanations in linguistics. In Raymond Hickey (ed.), The Handbook of Language Contact, 31-47. Malden, MA: Wiley-Blackwell Publishing.

Thomason, Sarah G. and Terrence Kaufman. 1988. Language Contact, Creolization and genetic linguistics. Berkeley: University of California Press.

Tippets, Ian. 2011. Differential object marking: Quantitative evidence for underlying hierarchical constraints across Spanish dialects. In Luis Ortiz-López (ed.), Selected 
Proceedings of the $13^{\text {th }}$ Hispanic Linguistics Symposium, 107-117. Somerville, MA: Cascadilla Proceedings Project.

Tomasello, Michael. 2003. Constructing a language: A usage-based theory of language acquisition. Cambridge: Harvard University Press.

Trask, Larry. 1997. The History of Basque. New York: Routledge.

Urrutia-Cárdenas, Hernán. 2003. Los clíticos de tercera persona en el española en el país vasco. Revista De Filología y Su Didáctica 26: 517-538.

Urrutia-Cárdenas, Hernán, and Teresa Fernández-Ulloa. 1997. Supresión del clítico acusativo de tercera persona en el español: América y país vasco. Boletín de Filología 36: $287-336$.

Von Heusinger, Kaiser, Georg A. Kaiser, and Alazne Arriortua. 2018. Differential Object Marking in ditransitive constructions in Basque. In Teresa Parodi (ed.), Proceedings of the VIII Nereus International Workshop "Referential properties of the Romance DP in the context of multilingualism", 25-61. Konstanz: Fachbereich Sprachwissenschaft der Universität Konstanz.

Walker, James. 2014. Variation Analysis. In Robert Podesva and Devyani Sharma (Eds.), Research Methods in Linguistics, 440-459. Cambridge: Cambridge University Press.

Weinreich, Uriel. 1953. Languages in Contact: Findings and Problems. Berlin: Mouton. Windford, Donald. 2003. An Introduction to Contact Linguistics. Oxford: Blackwell.

Zdrojewski, Pablo and Liliana Sánchez. 2014. Variation in accusative clitic doubling across three Spanish dialects. Lingua 151: 162-176.

Zagona, Karen. 2002. The Syntax of Spanish. Cambridge: Cambridge University Press.

Zuazo, Koldo. 2005. Euskara Batua: Ezina ekinez egina. Donostia-San Sebastián: Elkar.

Zubiri, Ilari. 1991. Gramática didáctica del euskera. Donostia: HABE.

Zurr, Alai, Elena Ieno, and Chris Elphick. 2010. A protocol for data exploration to avoid common statistical problems. Methods in Ecology and Evolution, 1 (1): $3^{-14}$. 